Article

\title{
The Design and Simulation of Natural Personalised Ventilation (NPV) System for Multi-Bed Hospital Wards
}

\section{Zulfikar A. Adamu ${ }^{\dagger, *}$ and Andrew Price ${ }^{\dagger}$}

School of Civil and Building Engineering, Loughborough University, LE11 3TU Leicestershire, UK; E-Mail: a.d.f.price@lboro.ac.uk

$\dagger$ These authors contributed equally to this work.

* Author to whom correspondence should be addressed; E-Mail: z.a.adamu@lboro.ac.uk; Tel.: +44-1509-223-526; Fax: +44-1509-223-980.

Academic Editor: Adrian Pitts

Received: 10 January 2015 / Accepted: 27 April 2015 / Published: 8 May 2015

\begin{abstract}
Adequate ventilation is necessary for thermal comfort and reducing risks from infectious bio-aerosols in hospital wards, but achieving this with mechanical ventilation has carbon and energy implications. Natural ventilation is often limited to window-based designs whose dilution/mixing effectiveness are subject to constraints of wind speed, cross ventilation, and in the case of hospital wards, proximity of patients to external walls. A buoyancy-driven natural ventilation system capable of achieving dilution/mixing was shown to be feasible in a preceding study of novel system called natural personalised ventilation (NPV). This system combined both architecture and airflow engineering principles of space design and buoyancy and was tested and validated (salt-bath experiment) for a single bed ward. This research extends the previous work and is proof-of-concept on the feasibility of NPV system for multi-bed wards. Two different four-bed ward types were investigated of using computational fluid dynamics (CFD) simulations under wind-neutral conditions. Results predict that NPV system could deliver fresh air to multiple patients, including those located $10 \mathrm{~m}$ away from external wall, with absolute flow rates of between $32 \mathrm{~L} \cdot \mathrm{s}^{-1}$ and 54 $\mathrm{L} \cdot \mathrm{s}^{-1}$ for each patient/bed. Compared to same wards simulated using window design, ingress of airborne contaminants into patients' breathing zone and summer overheating potential were minimised, while overall ward dilution was maximised. Findings suggest the NPV has potentials for enabling architects and building service engineers to decouple airflow delivery from the visualisation and illumination responsibilities placed upon windows.
\end{abstract}


Keywords: natural personalised ventilation (NPV); multi-bed hospital ward; airborne contaminants; overheating; mixing ventilation; computational fluid dynamics (CFD)

\section{Introduction}

In the United Kingdom (UK), mechanical ventilation contributes over $40 \%$ of energy allocated by typical hospitals for space conditioning [1]. Low energy alternatives have therefore been explored as intervention measures for existing stock of medium rise hospitals [2]. High ventilation rates from natural ventilation [3,4] make it an attractive option in the absence of cold temperate weather. Traditional window-based simple natural ventilation (SNV) systems used in UK hospitals are challenged by limitations of guidelines of the Department of Health [5] which specify that the width of any opened window must not exceed $100 \mathrm{~mm}$. The recent Health Building Notes [6] also emphasises the role of window restrictors in maintaining this maximum width. This $100 \mathrm{~mm}$ restriction is largely for security and safety reasons [5,6]. It is not evident from historical or contemporary literature that this area of opening has been fully studied in terms of its impact on adequate ventilation rates, specifically for dilution or airborne pollutants of pathogens. There is nevertheless research evidence pointing towards substantial increase in risk of cross-infection when such windows in multi-bed wards are closed in winter to save heating energy [7]. In summer, the current and long-term potential for overheating of naturally ventilated wards have also been shown [8] implying that better natural ventilation is desirable. There is also the issue of room air distribution, through displacement or mixing strategies and how this can affect clinical outcomes in multi-bed wards.

\subsection{Performance of Displacement Ventilation in Clinical Spaces}

The relatively new advanced natural ventilation (ANV) system uses buoyancy-driven airflow through displacement of stale air by cooler air supplied from low-level inlets instead of windows [9]. The ANV system (a wind-neutral system) is interesting because it circumvents the $100 \mathrm{~mm}$ restriction since air supply is not through windows. The windows remain as fixed glazed components for visual and illumination purposes. However, buoyancy-driven gravity current airflows are inseparably linked to displacement ventilation strategy in natural ventilation [10,11]. Recent findings about displacement ventilation in hospital wards however suggest a split in research opinion about the use of this approach for aseptic or clinical purposes. For example, a study of person-to-person cross-infection in mechanically ventilated offices revealed that displacement and under-floor air distribution (UFAD) strategies performed better overall than mixing strategy but the distance from infected to susceptible person was more important than airflow rate or mode of ventilation [12]. However, results from a study on displacement ventilation by Gao et al. [13] led to conclusions that with high temperature gradients, exhaled droplets are trapped at the breathing height of an adult. Likewise, it has been found [14] that mechanical displacement strategy was clinically inferior to mixing strategy because emissions from human pulmonary events (e.g., sneezing and coughing) occur in the lower zone of stratification whereas the mixing desired for dilution happens in the upper strata. They [14] established that under displacement ventilation driven by gravity currents, the momentum from emitted puffs in the occupied zone would be 
too strong, relative to the momentum of displacement air, thereby not allowing mixing and subsequent dilution. Other related studies on displacement ventilation [15,16], add weight to this argument, including a study [17] where experimental manikins were subjected to displacement, mixing strategies as well as in unventilated scenarios. In this case, it was also concluded that exhaled air travelled further at higher concentration in displacement ventilation, than when mixing is used. The balance of evidence from contemporary research, therefore, seems to favour mixing over displacement as far as dilution of airborne contaminants is concerned in clinical spaces. The implications of these studies are an important motivation for investigating alternative ways of achieving mixing ventilation in clinical spaces.

Mechanised mixing ventilation systems could provide mixing, but the use of electric energy to power fans makes it unattractive and unsustainable for wide scale adoption. Modern aseptic ventilation of hospital wards is usually achieved through personalised ventilation (PV) systems which provide an individual with dedicated air supply and control of the direction and flow rate of the air [18]. Yang et al. [19] have established that the integration of ceiling mounted (mechanised) PV systems with background mixing regime would lead to lower energy consumption at various room temperatures, than when mixing ventilation systems alone are used. Other relevant studies include: seat headrest personalized ventilation (SHPV) [20]; the performances of underfloor and PV systems [21]; as well as the use of PV under mixing and displacement strategies [22]. Yet, the electricity required to operate mechanical PV systems could be a drawback for their sustainable and wide scale adoption in hospitals. This downside of mechanised PV system inspired the development of a zero-energy version called natural personalised ventilation (NPV) [23]. The NPV system is designed to be used for wind-neutral (buoyancy-driven) conditions-where the air could come from, shielded points of air intake, or linked to underground labyrinths as done in advanced natural ventilation (ANV) [9].

\subsection{Personalised Ventilation (PV): Mechanical and Passive Options for Mixing Regime}

In the original NPV system, an elevated duct delivered fresh outdoor air directly over a patient in a single-bed ward (Figure 1a). In the process, the ingress of contaminated air into the patient's breathing zone and overall bed area is minimised. The NPV also achieved a mixing regime for the entire ward because of the subsequent rising of warmed (buoyant) air and its escape via a stack whose point of discharge was higher than the duct's inlet (Figure 1b). Follow-up investigation was carried out to validate the performance of the NPV using a scaled (1:20) Perspex model of the single-bed ward using salt-bath experimental modelling [24]. The flow regime was confirmed for interface layers (Figure 2) including the formation of "eddies" around the air supply duct. The scaled experimental validation of the NPV confirmed the descent of fresh air over the bed, the mixing regime as well as the tendency of fresh air to be "thrown" horizontally in a forward direction, which is a known characteristic of cold jet of air entering a warm space [10,25]. 


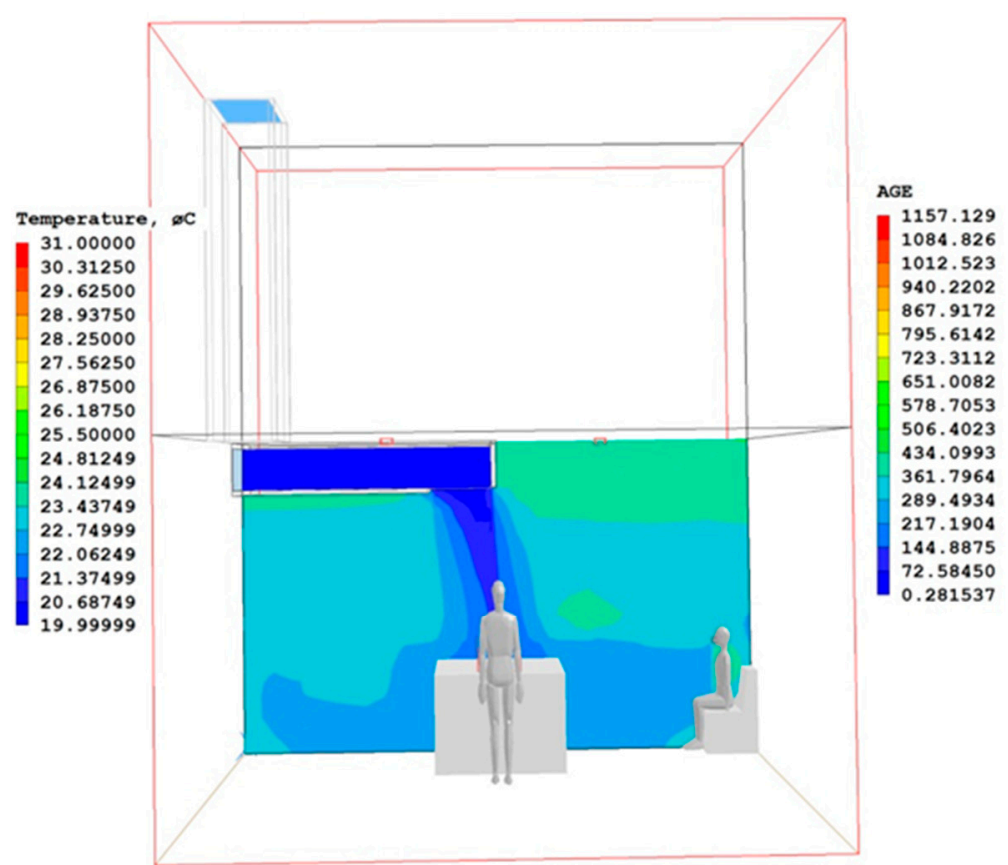

(a)

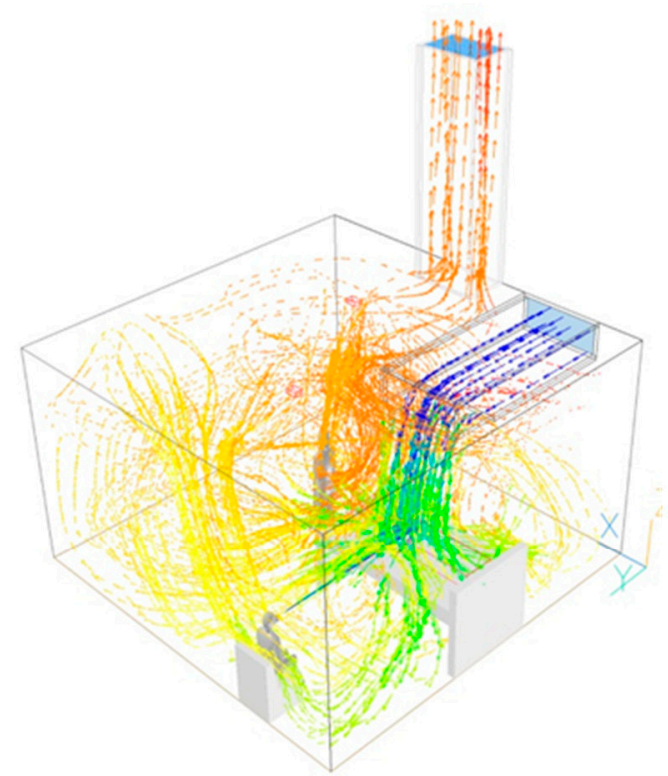

(b)

Figure 1. The natural personalised ventilation (NPV) system showing: (a) Fresh air delivered over patient's bed; and (b) The overall mixing regime achieved in the ambient space.

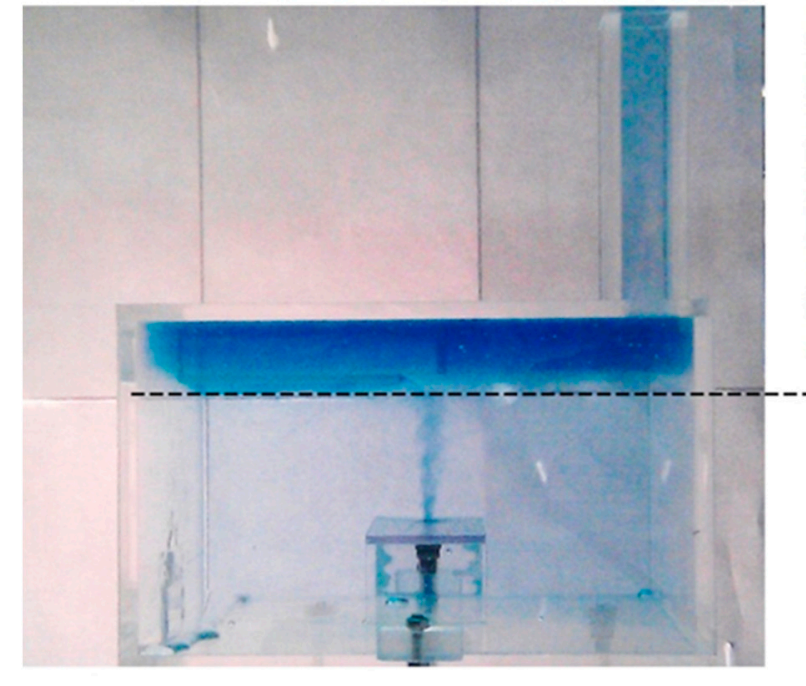

(a)

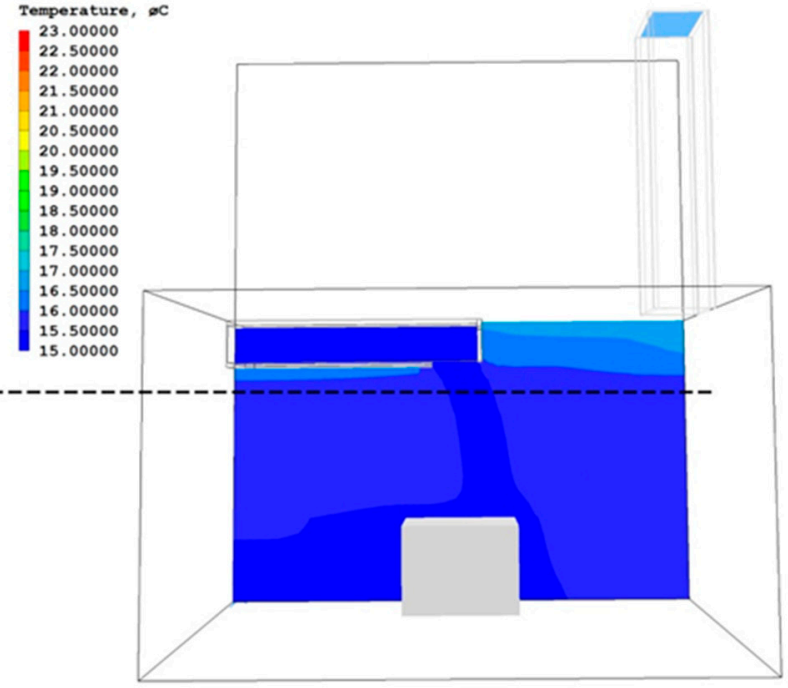

(b)

Figure 2. Compared interface layers in: (a) Salt-bath model; and (b) Computational fluid dynamics (CFD) model [24].

In summary, achieving dedicated personalised ventilation and mixing regime in occupied clinical spaces using the buoyancy-driven NPV system is an example of feasible low energy innovation. However, this approach requires integrating the architectural enclosure and bed layout with the design principles of buoyancy-driven natural ventilation system including internal heat loads and temperature differentials. 
The objective of this research is therefore, to scale the NPV system by customising its design for multi-patient wards. Salt-bath validation of the NPV [24] has provided the confidence needed to further investigate the feasibility of NPV system for multi-bed hospital wards using steady-state CFD. The choice of CFD for this investigation is that it has been shown [26] to be helpful and growing in reliability and wide spread adoption for ventilation-related research since 2002. Other studies [27,28] that have adopted CFD for modelling indoor air quality also support this notion. Subject to validation, CFD is in fact cheaper for studying person-to-person exposure to airborne contaminants [12].

\section{Materials and Methods}

\subsection{The CFD Application and Its Governing Equations}

The Parabolic Hyperbolic or Elliptic Numerical Integration Code Series (PHOENICS) is one of the earliest commercially available CFD code developed in 1980 [29]. It is used to quantitatively simulate the flow of fluids (e.g., air and water). PHOENICS utilizes the fundamental conservation model (Equation (1)) for balancing quantities (e.g., mass, energy, momentum) where:

$$
\text { [outflow from a cell }]-[\text { inflow to a cell }]=[\text { net flow in cell }]
$$

The single phase equation for conservation is expressed as shown in Equation (2):

$$
\frac{\partial(\rho \emptyset)}{\partial \mathrm{t}}+\frac{\partial}{\partial X_{k}}\left(\rho U_{k} \emptyset-\Gamma_{\phi} \frac{\partial \emptyset}{\partial X_{k}}\right)=\mathrm{S}_{\emptyset}
$$

where $\emptyset$ is a given variable; $S_{\varnothing}$ is the conventional source term; $\Gamma_{\phi}$ is the diffusive exchange coefficient and $U$ is the vector velocity. These are expressed through a relationship where the boundary conditions (e.g., $\left.S_{\mathrm{bc} 1}\right)$ and sources are on the right hand side of Equation (3):

$$
\frac{\partial(\rho \emptyset)}{\partial t}+\frac{\partial}{\partial X_{k}}\left(\rho U_{k} \emptyset-\Gamma_{\phi} \frac{\partial_{\emptyset}}{\partial \mathrm{x}_{\mathrm{k}}}\right)=S_{\varnothing}+S_{\mathrm{bc} 1}+S_{\mathrm{bc} 2}+\ldots+S_{\mathrm{bc} n}
$$

For modelling turbulence, PHOENICS has the option to implement the $k$ - $\varepsilon$ renormalisation group (RNG) model [30] for continuity (Equation (4)), momentum (Equation (5)), as well as the transport models for turbulence kinetic energy, $k$, (Equation (6)) and rate of dissipation, $\varepsilon$, (Equation (7)) respectively as follows:

$$
\begin{gathered}
\frac{\partial u_{i}}{\partial x_{i}}=0 \\
\frac{\partial u_{i}}{\partial x_{i}}\left(u_{i} u_{j}\right)=\frac{\partial}{\partial x_{j}}\left[\left(v+v_{t}\right) \frac{\partial u_{i}}{\partial x_{i}}\right]-\frac{1}{\rho} \frac{\partial_{p}}{\partial x_{i}} \\
\frac{\partial}{\partial x_{j}}\left(k u_{j}\right)=\frac{\partial}{\partial x_{j}}\left[\left(v+\frac{v_{t}}{\sigma_{k}}\right) \frac{\partial k}{\partial x_{j}}\right]+v_{t} S_{i j} \frac{\partial U_{i}}{\partial x_{j}}-\varepsilon \\
\frac{\partial}{\partial x_{j}}\left(\varepsilon u_{j}\right)=\frac{\partial}{\partial x_{j}}\left[\left(v+\frac{v_{t}}{\sigma_{\varepsilon}}\right) \frac{\partial \varepsilon}{\partial x_{j}}\right]+C_{\varepsilon 1} \frac{\varepsilon}{k} v_{t} S_{i j} \frac{\delta U_{i}}{\delta x_{j}}-C_{\varepsilon 2} \frac{\varepsilon^{2}}{k}-\frac{C_{\mu} \eta^{3}\left(1-\frac{\eta}{\eta_{0}}\right) \varepsilon^{2}}{1+\beta \eta^{3}} \frac{\varepsilon^{2}}{k}
\end{gathered}
$$

where $u_{i}$ represents mean velocity in $x_{i}$ direction, $u_{j}$ represents fluctuating velocity in $x_{j}$ direction; $p$ is mean pressure of fluid; $\rho$ is density of fluid; while $k$ is turbulence kinetic energy; and $\varepsilon$ is rate of dissipation. The turbulence constants are represented by: $\sigma_{k}, \sigma_{\varepsilon}, C_{\mu}, C_{\varepsilon 1}, C_{\varepsilon 2}, \eta_{0}$ and $\beta$. 


\subsection{Indoor Air Quality Metrics}

One method used to measure the effectiveness of ventilation systems is the contaminant removal efficiency (CRE) as proposed by Mundt et al. [31] and later by Cheong and Phua [32]. CRE is used to determine the level of exposure to contaminants for a person (or manikin) at the point or zone of inhalation. It is non-dimensional and typically expressed as a percentage. Given the concentration of a pollutant at return/exhaust point, $C_{R}$, and the concentration of same pollutant at a location of interest (e.g., breathing point) $C_{\exp }$, then CRE can be calculated as shown in Equation (8):

$$
C R E=\frac{C_{R}}{C_{\text {exp }}}
$$

Age of air $(\tau)$ is another metric, used to evaluate the quality of air because it indicates the time spent by air particles since entering a space [10]. In simple terms, Age of air determines the relative freshness or staleness of air, making it helpful for this kind of study. The predictions of percentage of people dissatisfied due to draught (PPDR) is based on PHOENICS' implementation of ISO 7730 for Class I buildings [33] also described in Awbi [10].

Two types of ward designs available in the UK were selected for the CFD investigation: the four-bed activity database (ADB) ward and the four-bed Nightingale Cruciform ward. Subsequent sections describe the studies carried out on these ward types. The specific boundary conditions for CFD modelling that were applied to these wards are described in the next section.

\subsection{Boundary Conditions for CFD Models}

The four-bed ADB ward was re-created in PHOENICS, to serve as the Base Case upon which the performance of the NPV system would be appraised as an alternative. The computational domain of the four-bed ADB ward was modelled without the toilet or store areas but including the lobby which separates them, giving a net area of $62.25 \mathrm{~m}^{2}$. This domain was meshed with $90 \times 100 \times 45(405,000)$ cells. This fine mesh was arrived at after carrying out tests (coarse, medium and fine) on the best grid resolution that would produce reliable results while being computationally affordable. All envelope surfaces were assumed to be adiabatic. The internal heat load utilised for the CFD simulation was based on assumed peak occupancy and equipment utilisation. For lighting, using an 80:20 radiation-to-convection ratio for ceiling mounted fluorescent lighting as contained in CIBSE Guide A [34], the floor re-radiated $127 \mathrm{~W}$ while the lighting fixtures themselves produced a total of $28 \mathrm{~W}$, giving a combined lighting load of $155 \mathrm{~W}$. Heat load from miscellaneous medical equipment was assumed to contribute a total of $300 \mathrm{~W}$. In the CFD model, each patient emitted $80 \mathrm{~W}$ of heat while standing healthcare workers and seated visitors were allocated $100 \mathrm{~W}$. A peak-time total of eight persons (healthcare workers and visitors) were assumed in addition to four patients. This assumption would represent a fully occupied ward, allowing the resilience of the window openings to cope with high internal heat loads to be evaluated.

The $k-\varepsilon$ renormalisation group (RNG) model and the boussinesq approximation model were used for turbulence and buoyancy, respectively. The effect of wind was kept minimal at a fixed inlet velocity of $0.2 \mathrm{~m} / \mathrm{s}$ for the window cases: (in order to make the airflow through the window case as close as possible to the NPV, this low wind speed was allowed since windows cannot constantly guarantee zero wind conditions like the NPV). For the NPV model, airflow was driven by buoyancy forces only. A steady- 
state ambient temperature of $18{ }^{\circ} \mathrm{C}$ was used. For simulating released airborne pathogens, a surrogate (passive scalar) airborne contaminant of dimensionless value and initial concentration of $100 \%$ was assumed. Passive scalar contaminants have been shown [35,36], to be adequate in representing airborne contaminants (droplet nuclei) whose size does not exceed $1 \mu \mathrm{m}$ in CFD modelling studies. Cox and Wathes [37] also reported that a contaminant density of $1.1 \mathrm{~kg} / \mathrm{m}^{3}$ (similar to that of air) is widely accepted for computational applications. The contaminant was assumed to be produced via a cough at a mass flow rate of $0.005 \mathrm{~kg} / \mathrm{s}$ and temperature of $30{ }^{\circ} \mathrm{C}$, from an adult male. The mouth area was taken as $0.0049 \mathrm{~m}^{2}$ which is within the range found by Gupta et al. [38]. The cough model was assumed because it is not only representative of a possible source of a single, forceful emission, but also for the presumption that five minutes of talking could generate as much bio-aerosols as a single cough [39]. The contaminant source is assumed to be a sitting visitor, whose back is to the external wall (position " $X$ " in Figure 3) with the mouth at an elevation of $1.05 \mathrm{~m}$, for a seated person.

The second type of ward simulated is the Nightingale Cruciform Ward. As in the ADB ward, a mild non-winter scenario was assumed, when outdoor temperatures could be $18{ }^{\circ} \mathrm{C}$. Similar boundary conditions used in the ADB ward (i.e., internal heat load, occupancy and airborne contaminants) were retained, with the exception of the cell density in computational domain which was now meshed using $105 \times 110 \times 50(577,500)$ cells. The same pollutant removal metric (i.e., CRE) applied in the ADB ward was also used to further predict the contaminant removal/dilution capacity of the Nightingale Cruciform ward.

\section{Study 1: The ADB Ward}

The design of the NPV system integrates architectural layout (e.g., bed locations and height of headroom) with natural ventilation principles as earlier demonstrated in the original study of the NPV [23]. For this study, these integrated design factors are described in the next sub-sections.

\subsection{Architectural Considerations, Materials and Methods}

The standard four-bed ADB ward (Base Case) has a combined bed area of $56.25 \mathrm{~m}^{2}$ and a floor to ceiling height of $3.6 \mathrm{~m}$ gives it a volume of $202.5 \mathrm{~m}^{3}$ (Figure $3 \mathrm{a}$ ). The en-suite shared bathroom found in this type of ADB ward (with mechanical extract fan) was ignored in order to focus on the natural (buoyancy-induced) airflow regime. Each bed is within an area approximately $3.3 \mathrm{~m} \times 3.9 \mathrm{~m}$ (Figure 3a). The natural ventilation openings of the Base Case were side-hung windows, modelled as five bays of side-hung casement windows. Given the $100 \mathrm{~mm}$ maximum restrictions [5], the total effective area of each opening was found to be $0.15 \mathrm{~m}^{2}$. This area of opening was modelled as a vertical orifice measuring $0.125 \mathrm{~m}$ by $1.2 \mathrm{~m}$ on the external wall. The $125 \mathrm{~mm}$ opening marginally exceeds the $100 \mathrm{~mm}$ requirements because the upper and lower "triangular" portions of the open window were added to the horizontal $100 \mathrm{~mm}$ width. The total area of window opening is $0.6 \mathrm{~m}^{2}$.

For the NPV system in the ADB ward, four ducts (each measuring $0.3 \mathrm{~m} \times 0.6 \mathrm{~m}$ in cross section) and two supplementary ducts (each measuring $0.4 \mathrm{~m} \times 0.7 \mathrm{~m}$ ) were used for fresh air supply. The total area of air inlets was therefore $1.28 \mathrm{~m}^{2}$ which is $53 \%$ more than total area of window openings. Due to the need to ensure fresh air was supplied to the exact location on each of the four beds, two possible 
designs of the NPV system that were considered and modelled are: the Side-Side Duct Arrangement; and the Top-Bottom Duct Arrangement (Figure 3). The three-dimensional positions of the Side-Side and Top-Bottom NPV ducts along (Figure 3b) represent the distinct feature of the NPV cases being investigated for the ADB ward. The clear headroom and height of opening for each duct in the Side-Side arrangement was $2.45 \mathrm{~m}$ while for the Top-Bottom arrangement, the headroom was $2.15 \mathrm{~m}$. The exhaust stack was proportionately sized in cross section as $1.28 \mathrm{~m}^{2}$, representing $1 \%$ of the net floor area as done in Lomas and Ji [40] for sizing advanced natural ventilation systems. The central exhaust stack was located internally along the external wall (Figure 3a) to ensure balanced access of stale to the exterior. The stacks were assumed to rise up to $2.5 \mathrm{~m}$ above the roof level. The longest ducts meant for the furthest beds were required to span a distance of $5.4 \mathrm{~m}$ (Figure 3a).

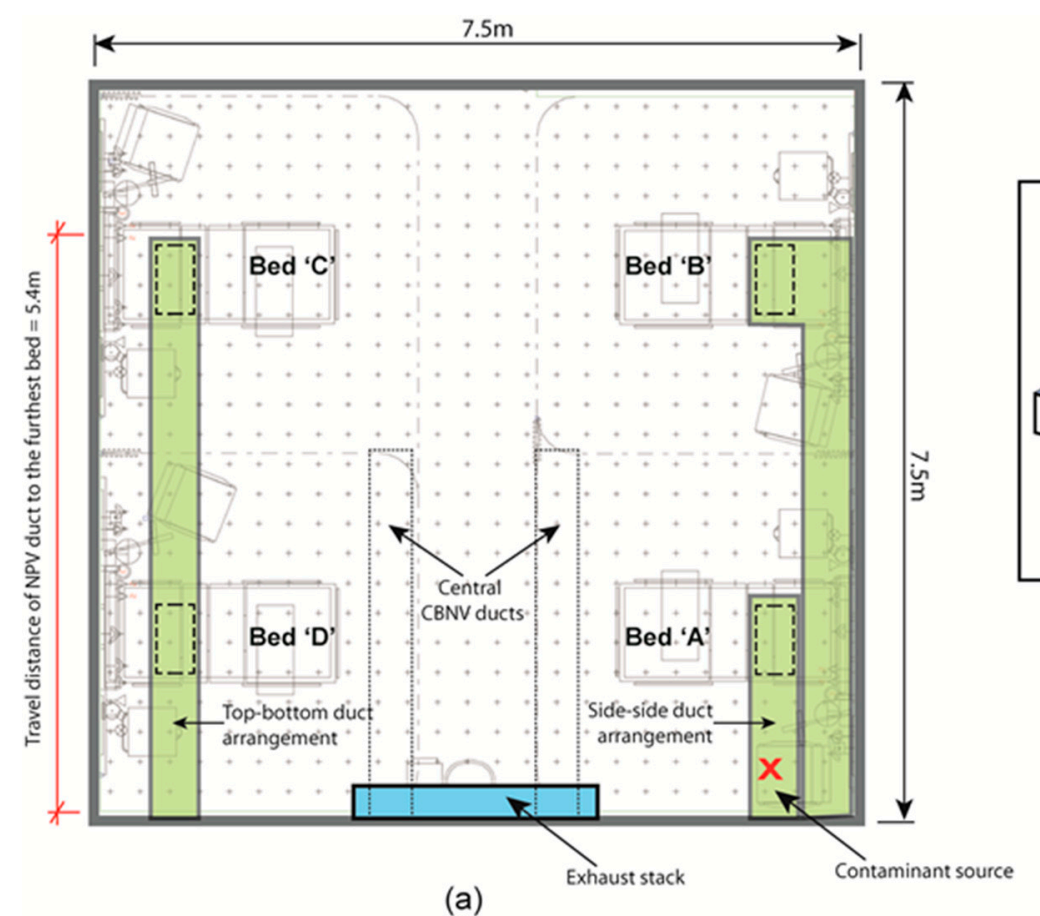

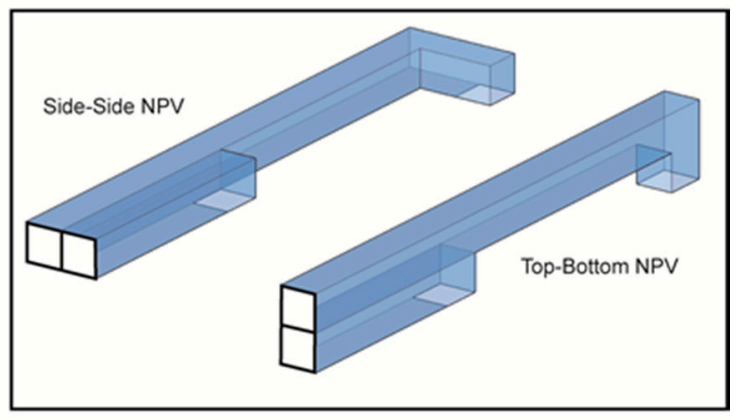

(b)

Figure 3. Layout of activity database (ADB) ward showing: (a) Plan view of Side-Side and Top-Bottom NPV duct locations, central CBNV ducts and two possible locations of exhaust stacks; as well as (b) The NPV duct designs in 3D.

\subsection{Results of the ADB Ward}

The predictions from CFD are in agreement with findings from literature that with displacement strategy (i.e., Base Case windows), fresh air from the side-hung openings flood the space at floor level (Figure 4). As the same orifice serves as air outlet, the mean age of air of at the floor is $2100 \mathrm{~s}$, before the currents rise upwards upon reaching the opposite wall (Figure 4d). Upon reaching the opposite wall, the air currents begin a return sweep with a mean Age of air at bed height of between 2730s and 2940s. Thermal stratification is clear from the predictions of ward temperature (Figure 4a), PMV (Figure $4 \mathrm{~b}$ ) and Age of air (Figure 4c). The temperature at $1 \mathrm{~m}$ (bed heights) is generally around $27^{\circ} \mathrm{C}$, indicating a rise of around $9{ }^{\circ} \mathrm{C}$ from ambient (outdoor) temperature. The overall mean ward temperature at head height is $29{ }^{\circ} \mathrm{C}$. There would be pockets of stale warm air collecting at the celling with values 
approaching $36{ }^{\circ} \mathrm{C}$. The relative air change rate predicted from the CFD simulations for the Base Case is $1.8 \mathrm{ACH}$.
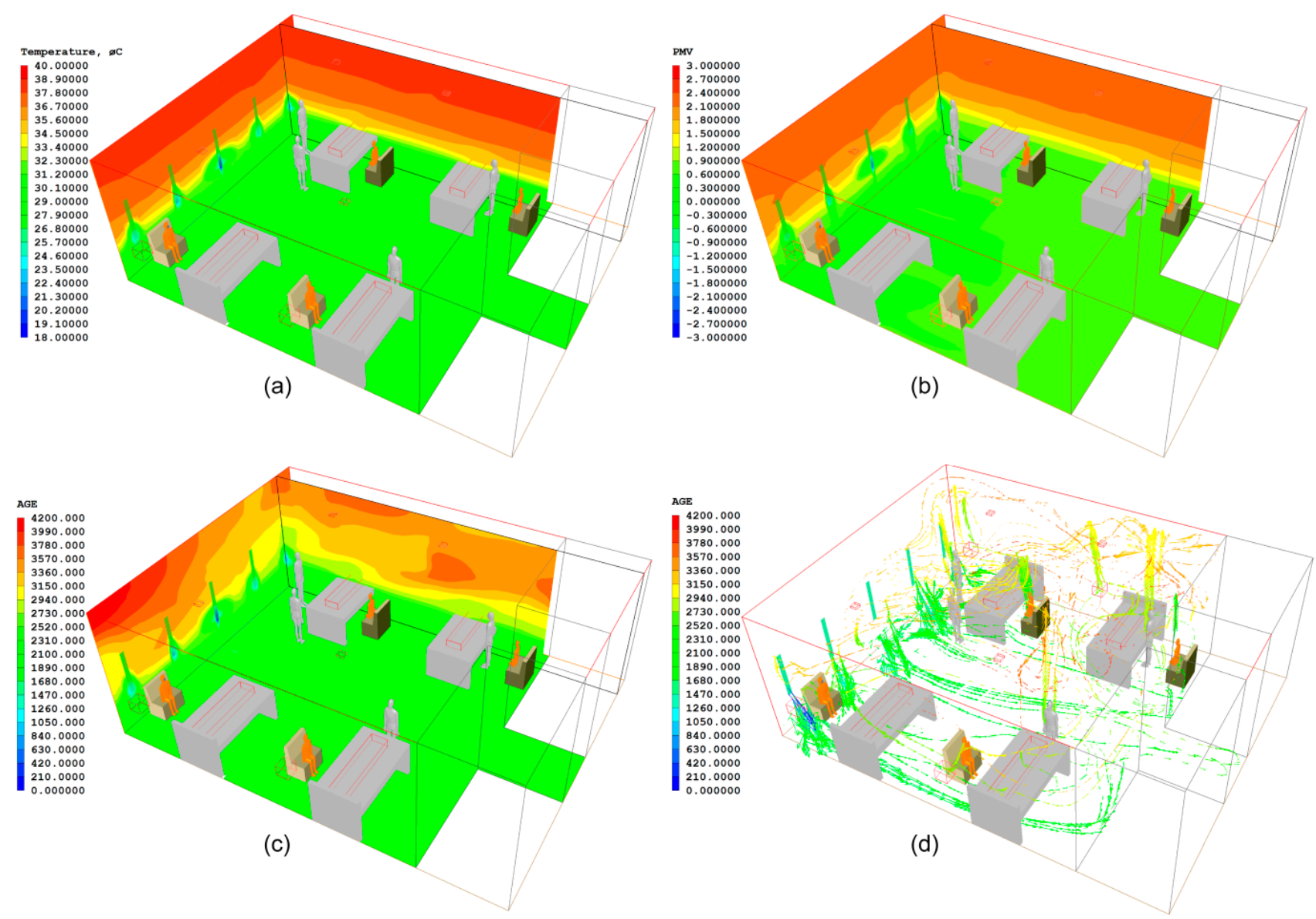

Figure 4. Airflow characteristics of the base case design showing contours of: (a) Temperature; (b) PMV; (c) Age of air; and (d) Streamlines of displaced air particles as they flood the space.

When the ADB ward is fitted with the NPV system, the shorter ducts of both Case 1 (Side-Side NPV) and Case 2 (Top-Bottom NPV) bring in fresh air with a horizontal throw as expected (Figure 5). The Top-Bottom design delivers greater volume of fresh air for the longer ducts, while for the Side-Side design, the elbow (corner) in the longer duct leads to a reduction in flow velocity and subsequently air flow rates (Figure 5a). In both cases, airflow within the ducts can be described as steady laminar (Rayleigh number, $R a<10^{5}$ ). In the Top-Bottom duct arrangement (Figure $5 \mathrm{~b}$ ) the presence of canopy is useful re-directing air from the top duct unto the bed, whereas air from the bottom (shorter) duct experiences a horizontal throw.

In all NPV cases, the mean Age of air at bed height is $\approx 240 \mathrm{~s}$ and temperature stratification gradient is much less evident. There is potential for draught to be experienced by the patients, due to the instant discharge of fresh air over the beds with minor trubulence. The predictions of PPDR (for both types of NPV designs) show that for an outdoor simulation temperature of $18{ }^{\circ} \mathrm{C}$, between $11 \%$ and $25 \%$ of patients may experience draught (Figure $5 \mathrm{c}, \mathrm{d}$ ). This proportion of dissatisfied persons would expectedly be higher at a lower ambient temperature. The relative air change rates predicted from the CFD simulations are: 4.8 ACH for Side-Side NPV and 5.2 ACH for Top-Bottom NPV. 

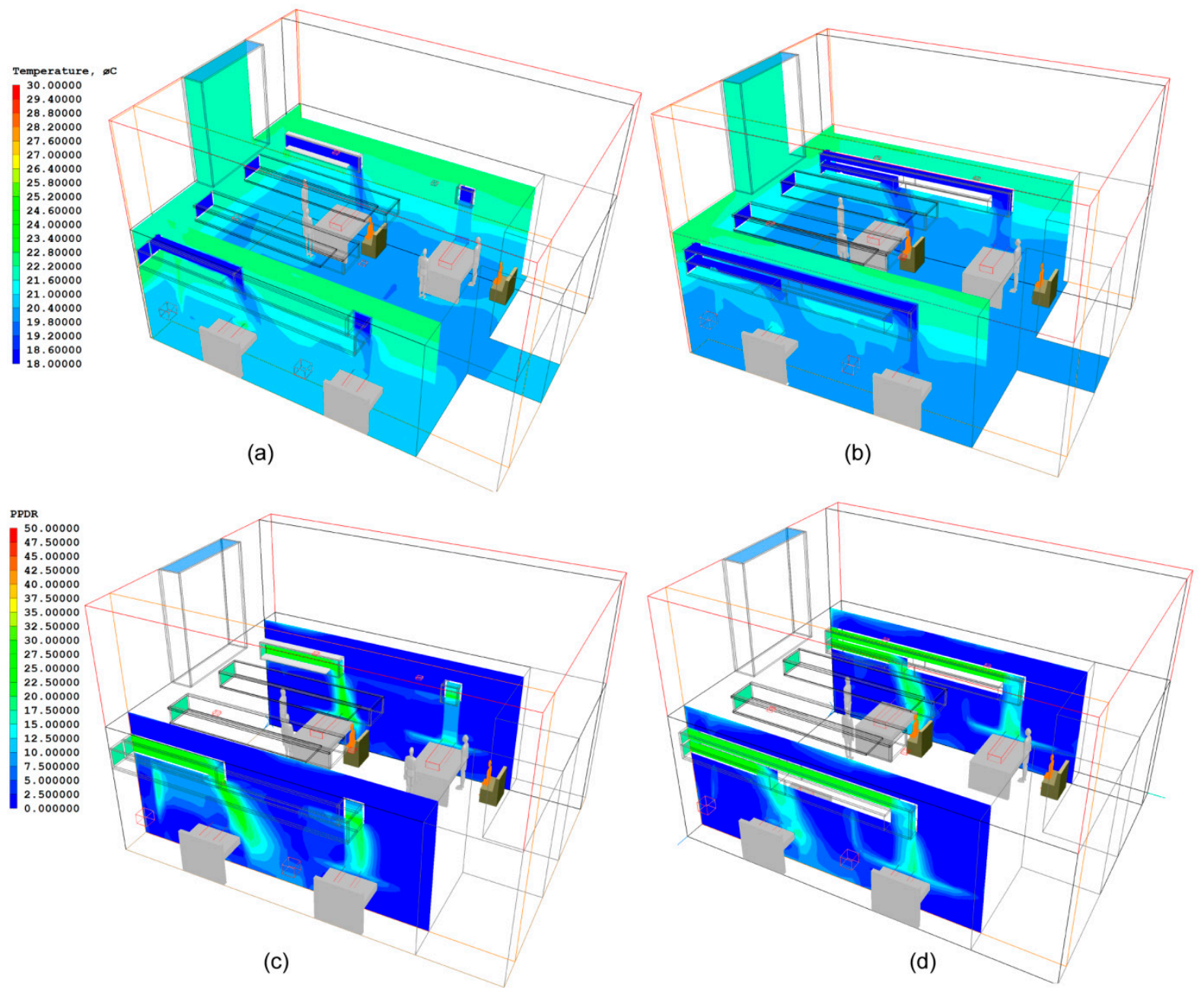

Figure 5. Temperature contours for: (a) NPV Case 1; and (b) NPV Case 2 showing horizontal throw of fresh air from shorter ducts; with draught potential for (c) NPV Case 1; and (d) NPV Case 2.

The distinct designs of the NPV ducts in Case 1 and Case 2 also have marginal implications on the speed of incoming air within the ducts and hence on airflow rates. From the steady-state CFD results of the Side-Side design (Case 1), the computed mean velocity of air at the discharge orifice is $0.31 \mathrm{~m} / \mathrm{s}$ for the shorter duct and $0.26 \mathrm{~m} / \mathrm{s}$ for the longer duct. The reduced velocity in the longer duct is due to the "L" shape bend which leads to pressure loss, and not particularly due to distance. This was confirmed in the Top-Bottom design, where the mean velocity of $\approx 0.3 \mathrm{~m} / \mathrm{s}$ is maintained for both long (top) and short (bottom) ducts. Relative to the cross-sectional area of duct, this air speed gives each patient an absolute mean flow rate of $0.0324 \mathrm{~m}^{3} / \mathrm{s}$ or $32.4 \mathrm{~L} \cdot \mathrm{s}^{-1}$.

The airborne contaminants originate from source location (Figure 3a, Position ' $X$ ") in all Cases. The concentrations were calculated at the assumed (horizontal and vertical) position of a sleeping head for two bed positions (Figure 6). In all Cases, the airborne contaminants are able to travel further across the ward with a relatively high concentration at a distance of up to $8 \mathrm{~m}$ from the source. However, in the Base Case, the concentration across the width of Bed "A" builds up from $7 \%$ up to $13.9 \%$ before it attenuates to $\approx 8 \%$ across Bed "B" (Figure 6a). In the NPV Cases, however, the concentration across Bed "A" drops from $\approx 12 \%$ down to $\approx 3 \%$ in Case 1 (Side-Side) and to $\approx 2 \%$ in Case 2 (Top-Bottom). Across 
Bed " $\mathrm{B}$ " the concentration is $\approx 2 \%$ for Case 1 and $\approx 1 \%$ for Case 2 (Figure $6 a$ ). The marked differences in the horizontal spread of the contaminants in the three Cases can be appreciated from the contour plots for the Base Case (Figure 6b), Case 1 (Figure 6c) as well as Case 2 (Figure 6d).

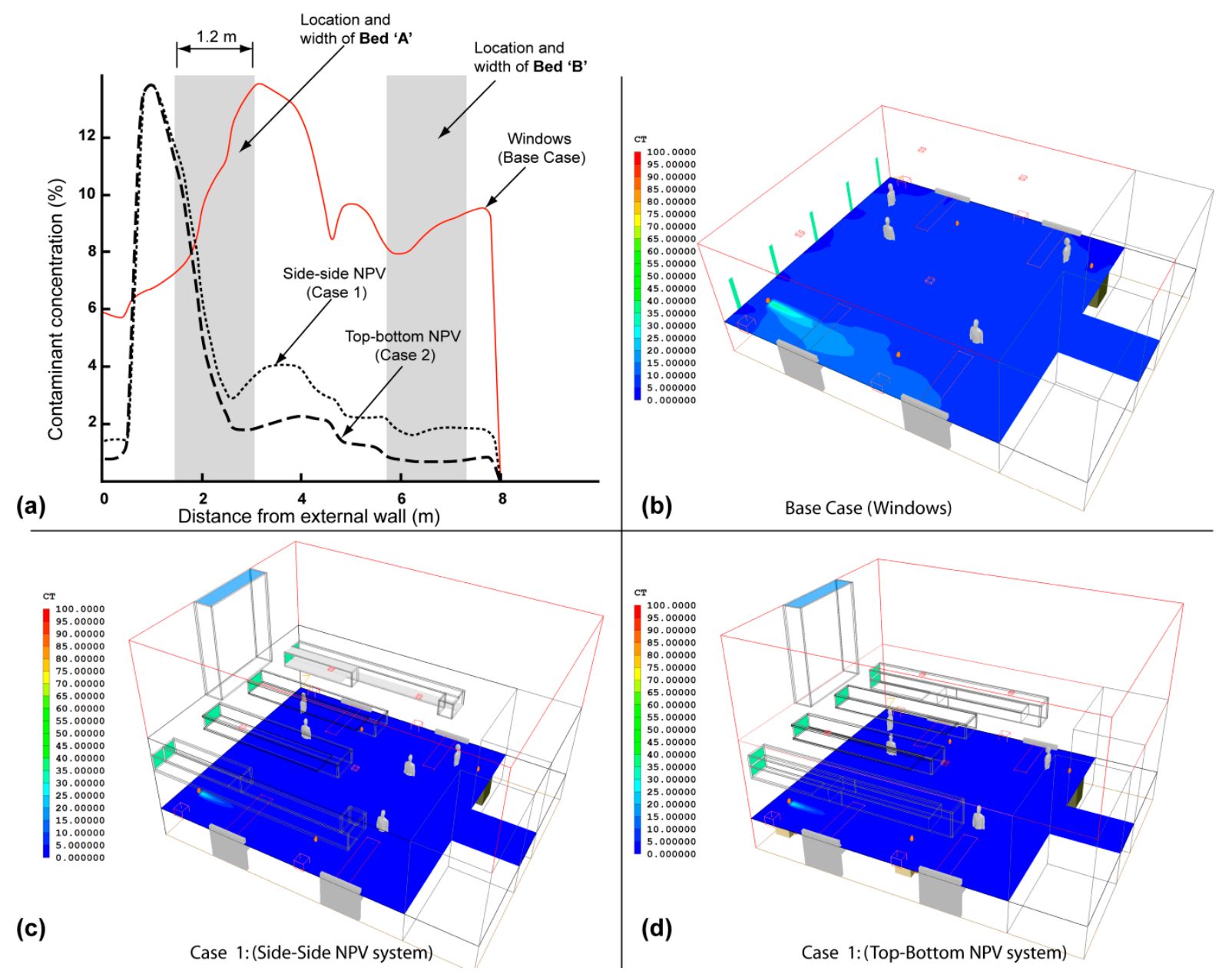

Figure 6. Predicted contaminant (CT) concentration results for: (a) All three cases at height of $1.05 \mathrm{~m}$ along trajectory of release; and 2D horizontal axis contours for (b); Base Case (c) Case 1; and (d) Case 2.

Contaminant removal efficiency (CRE) was estimated at assumed head position on all four beds as well as at standing height in the centre of the ward. The CRE for each position in the Base Case is significantly higher than at similar positions for Case 1 and Case 2 (Table 1). Although the NPV in Case 2 (Top-Bottom) offers relatively better CRE values than Case 1 (Side-Side), both systems are significantly superior to the $\mathrm{CRE}$ of Base Case, by a minimum order of $34.4 \%$ (Bed C, in Case 1) and a maximum order of $80 \%$ (Bed D in Case 2).

The airflow characteristics the Top-Bottom and Side-Side duct arrangements differ marginally in airflow rates, but the differences in the direction of airflow are significant. The short ducts of both cases are observed to deliver fresh outdoor air into the space with an expected lateral throw in the same direction as the duct. In previous NPV studies [23], such horizontal throw led to the ducts being offset backwards by $0.3 \mathrm{~m}$ from the desired point of discharge. This horizontal throw is also present in the 
multi-bed use of NPV where the discharged air from shorter ducts partially overshoots the bed (Figure 7). An improvement was needed to channel the discharged air directly over the bed.

Table 1. The contaminant removal efficiency (CRE) values computed at five locations for all three Cases in ADB ward.

\begin{tabular}{cccccc}
\hline Cases & Bed-A & Bed-B & Bed-C & Bed-D & Ward Centre \\
\hline Windows (Base Case) & 0.73 & 0.57 & 0.32 & 0.30 & 0.40 \\
Side-Side NPV (Case 1) & 0.34 & 0.24 & 0.21 & 0.09 & 0.20 \\
Top-Bottom NPV (Case 2) & 0.30 & 0.18 & 0.13 & 0.06 & 0.16 \\
Difference between Base Case and Case 1 & $53.4 \%$ & $57.9 \%$ & $34.4 \%$ & $70.0 \%$ & $50.0 \%$ \\
Difference between Base Case and Case 2 & $58.9 \%$ & $68.4 \%$ & $59.4 \%$ & $80.0 \%$ & $60.0 \%$ \\
\hline
\end{tabular}

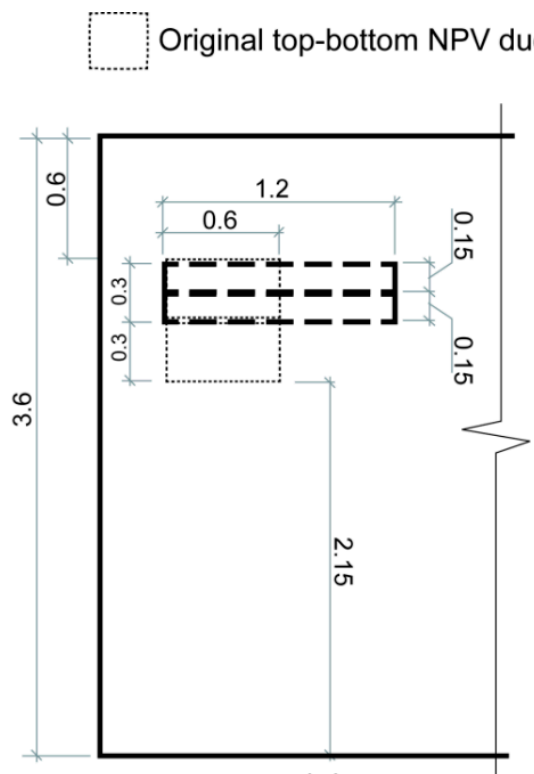

(a)
エニニコRedesigned top-bottom NPV ducts

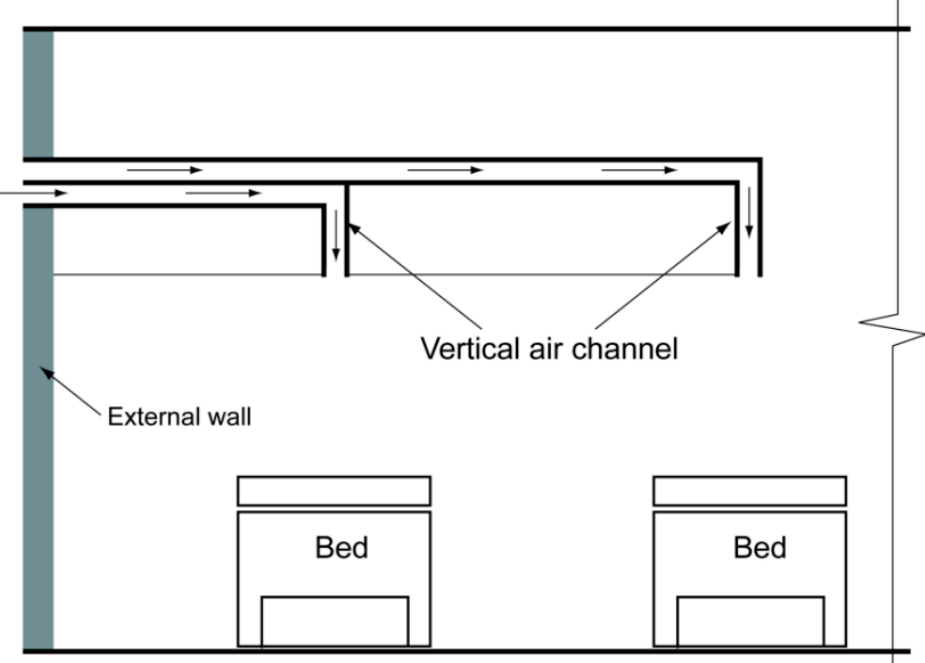

(b)

Figure 7. Re-design of the Top-Bottom NPV duct to create vertical air discharge channels, shown as: (a) External facade view; and (b) Cross-sectional view.

\subsection{Improved Design of NPV Duct Using Vertical Air Channels}

To constrain the horizontal throw of air, a channel was created to direct the flow vertically and downwards, unto the middle of the bed. It was necessary to work around the architectural features of the ward (e.g., headroom). The vertical channel in the Top-Bottom concept was adopted for the shorter duct but to avoid encroaching into the headroom (currently $2.15 \mathrm{~m}$ ), both ducts were compressed from a cross-sectional area of $0.6 \mathrm{~m} \times 0.6 \mathrm{~m}$ into $0.15 \mathrm{~m} \times 1.2 \mathrm{~m}$. The same area of opening was achieved with different (flattened) geometry (see Figure $7 \mathrm{a}$ ). This compression freed up a height $0.3 \mathrm{~m}$ which was used to elevate the lower duct. The new headroom and height of opening for the lowest Top-Bottom duct (Figure 7b) became $2.45 \mathrm{~m}$.

For Case 2 (Top-bottom NPV) the new design simulated in CFD produced desired results (Figure 8b) without much horizontal throw (Figure 8a). The horizontal throw was largely eliminated by the use of vertical channels, as observed from the beds with shorter ducts. This vertical channel helps with discharge of fresh air directly over the patient, without any significant loss of head room. 

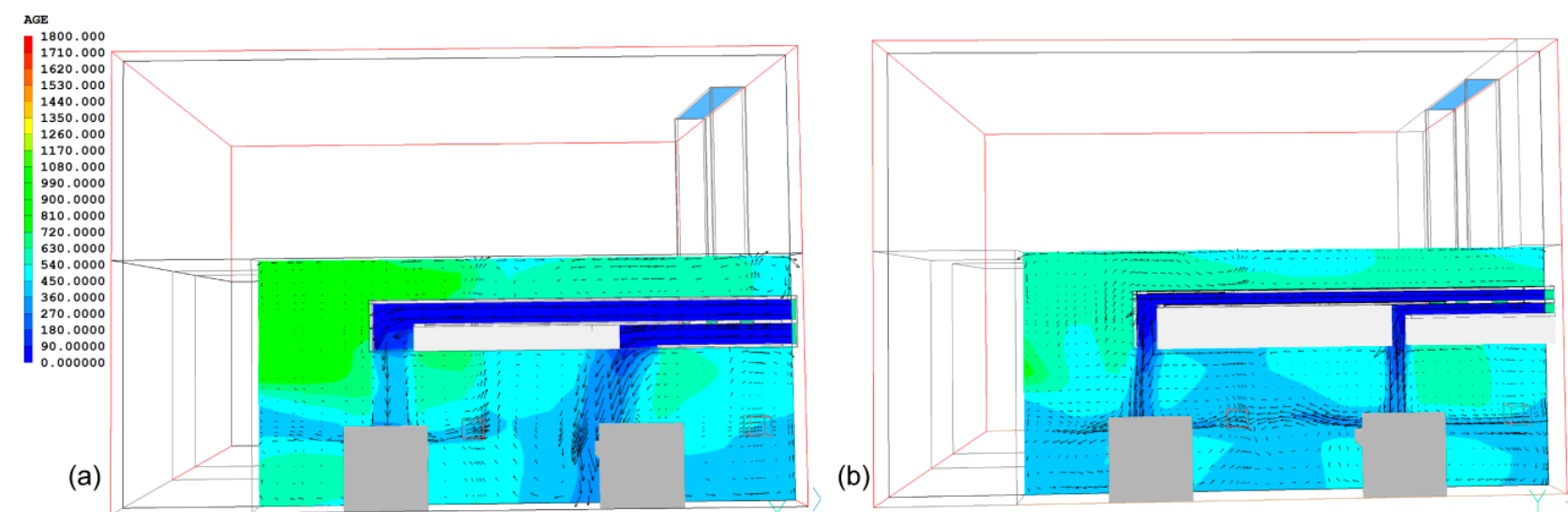

Figure 8. 2D contours and vectors indicating directionality of air in: (a) The original Top-Bottom design; (b) The narrow vertical air discharge channels.

\section{Study 2: The Nightingale Cruciform Ward}

To further test the scalability and adaptability of the NPV system to different design scenarios, an alternative four-bed ward (Nightingale Cruciform ward) developed by an architectural practice was modelled and simulated. This ward had significantly different spatial and bed layout requirements. The next subsections describe the NPV design considerations and the results obtained from the simulations carried out.

\subsection{Architectural Considerations, Materials and Methods}

The floor area of the Nightingale Cruciform ward [41] is approximately $107.5 \mathrm{~m}^{2}$, with an en-suite bathroom measuring $9.5 \mathrm{~m}^{2}$ (Figure 9). Disregarding the bathroom space which is often fitted with extract fans, the effective volume of the ward space to be naturally ventilated is $352.8 \mathrm{~m}^{3}$, assuming a uniform floor to ceiling height of $3.6 \mathrm{~m}$. The ward has two window bays, located at two corners of the ward. These corners were designated as waiting and dining areas (Figure 9a,b) and for the purpose of this investigation, their windows were assumed to be top-hung. Following the DH regulations that restrict vents to $100 \mathrm{~mm}$ width, the effective area of ventilation were taken as three (lower, middle and upper) equidistant vents measuring $0.18 \mathrm{~m}^{2}$ each, with a distance of $1.2 \mathrm{~m}$ between the lower and upper vents. The total area of window openings is $1.08 \mathrm{~m}^{2}$.

The collapsible partitions which demarcate each bed space were presumed to be fully stretched out, to represent a scenario that might impede natural airflow. This is because other than airflow rates, two other parameters: airflow pattern and airflow direction, are known to affect the migration of airborne contaminants in ventilated spaces $[42,43]$.

For testing the NPV system in the Nightingale Cruciform ward, four ducts-A, B, C and D (Figure 9b) each with cross-sectional flow area of $0.18 \mathrm{~m} \times 1.2 \mathrm{~m}$ were created at the top for supplying fresh air over corresponding patient beds (Figure 9c). The total area of NPV inlets is $0.86 \mathrm{~m}^{2}$, which is $80 \%$ of the total area of the window openings. Based on learning from the improved Top-Bottom duct design of $\mathrm{ADB}$ ward (i.e., use of flattened ducts and narrow air discharge channels), all ducts in the Nightingale Cruciform Ward were also modified to achieve similar vertical descent of cool fresh air directly over each patient. The air discharge channels had to be oriented along the length of each bed. 
The longest NPV duct (Duct C) was required to transport fresh air up to $10 \mathrm{~m}$ to Bed C. Four exhaust stacks (each measuring $0.5 \mathrm{~m} \times 0.65 \mathrm{~m}$ ) were created at each corner of the ward to remove stale air. These stacks represent located at the four corners represent edge-out and centre-out strategies as defined in [40]. A plenum-like space $0.6 \mathrm{~m}$ high was left above the ducts for buoyant stale air to collect and make its way towards the exhaust stack. The lowest natural ventilation inlets in waiting and dining areas were retained in order to supply air to these spaces.

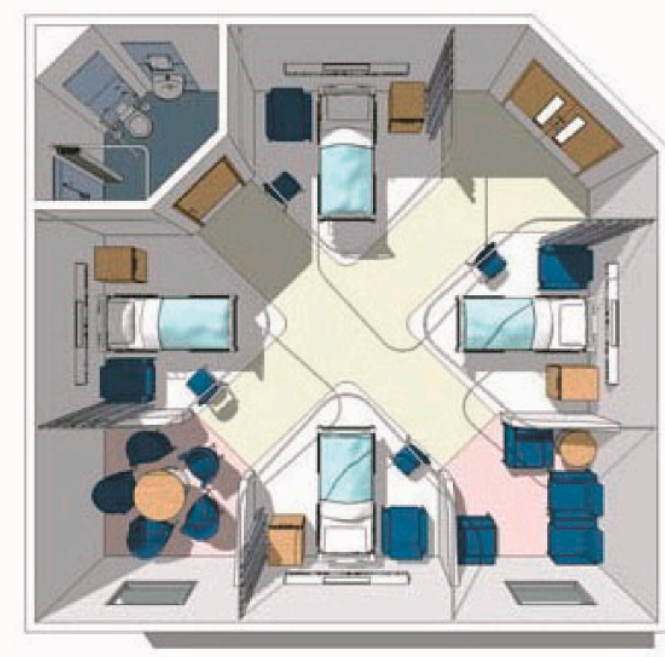

(a)
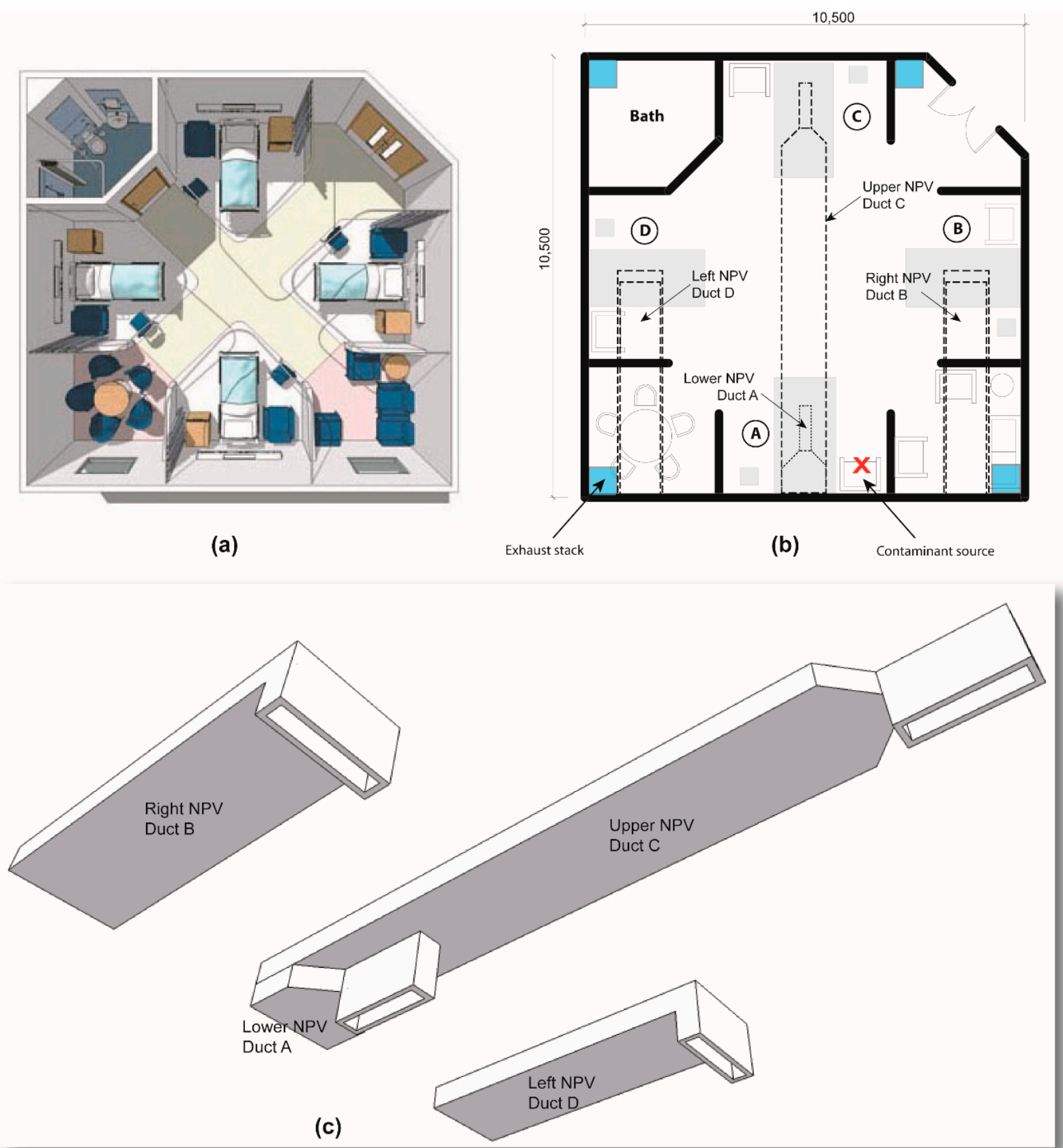

Figure 9. Design of original Cruciform ward ${ }^{\circledR}$ Nightingale Associates showing: (a) Top view; (b) NPV ducts fitted in plan; (c) Vertical air channel for NPV ducts in 3D orientation over four beds. 


\subsection{Results of the Nightingale Cruciform Ward}

In the base case of the Nightingale Cruciform ward, the waiting and dining areas are flooded by cascading cooler outdoor air from their windows. The air currents are then displaced towards other parts of the ward, but presence of partitions in both areas constrains the free flow of fresh air (Figure 10a,b). The top-hung windows acted like dual openings, with lower vents bringing in fresh air and upper vents taking out stale air (Figure 10c).

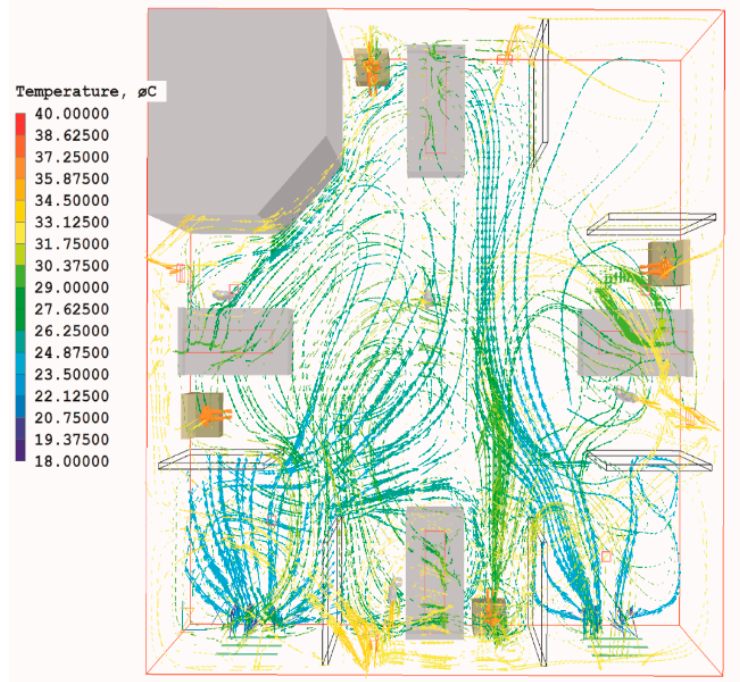

(a)

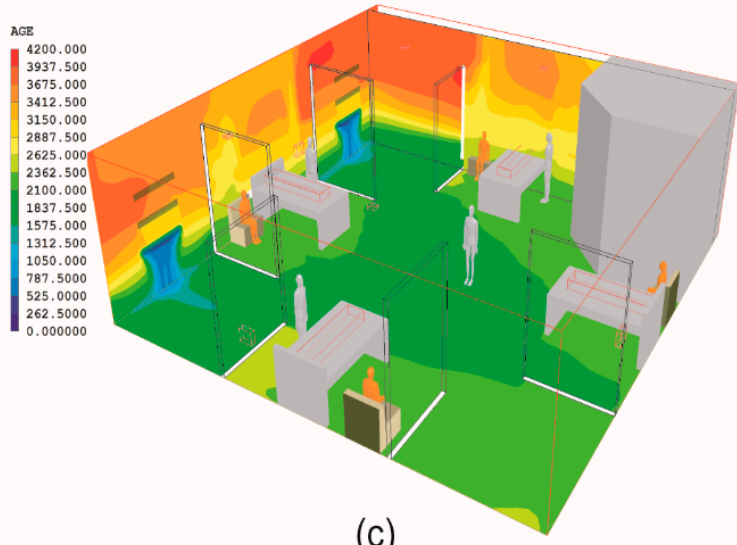

(c)

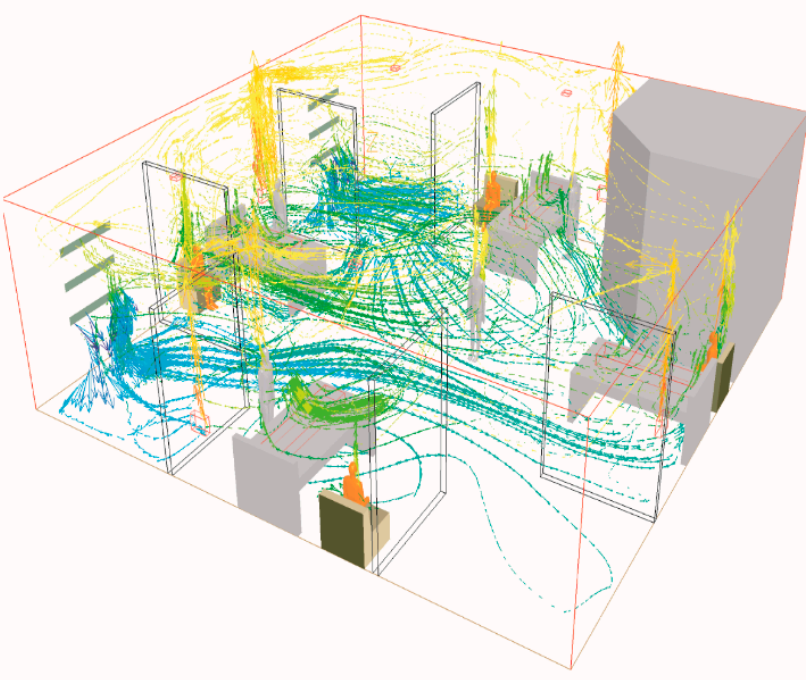

(b)

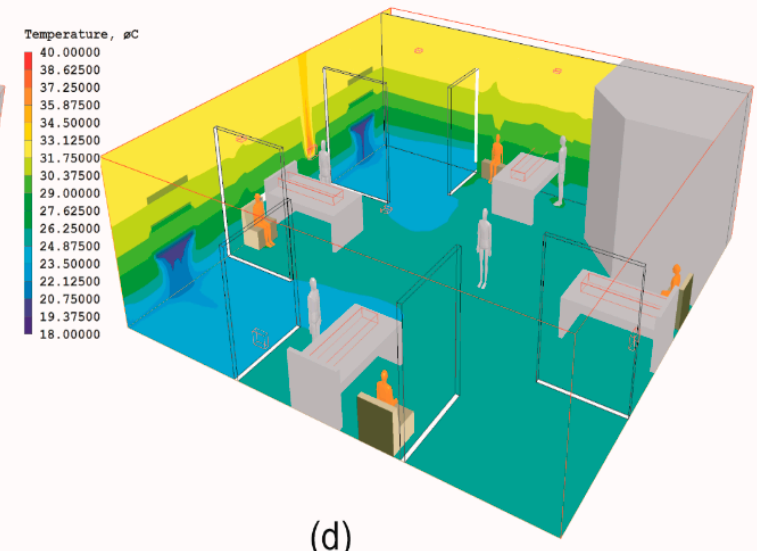

(d)

Figure 10. Airflow characteristics in Cruciform Ward showing pattern and direction of air movement in: (a) Top view; and (b) Isometric view; with contours for (c) Age of air; (d) Stratified temperature.

Deterioration in Age of air $(\tau)$ at floor level (Figure 11c) means fresh air creeps towards the interior, from the central part of the ward $(\tau=1575 \mathrm{~s})$ to the partial detriment of Bed A (see Figure 10a), which is actually nearer to the facade. The side beds (i.e., Beds B and D) are also partially bypassed by the gravity currents of fresh air. As the air currents make a return sweep after encountering the opposite wall, the Age of air at bed level is up to 2625 s. In other words, the partitions separating each bed area in the Nightingale Cruciform ward are seemingly causing a delayed entrance of fresh air into the bed zones. This is with the exception of Bed C, which is furthest from the window but is directly in the path 
of creeping and rising gravity currents (Figure 10b). Overall, the Age of air at the floor of furthest end of the ward is similar to the Age predicted for the ADB ward $(\approx 2100 \mathrm{~s})$.

The $18^{\circ} \mathrm{C}$ temperature of outdoor air rapidly increases towards the inner part of the ward where, even at floor level, it is already up to $24{ }^{\circ} \mathrm{C}$ around the furthermost bed (Figure 10d). Like with the ADB ward, the temperature of the Nightingale Cruciform ward is stratified, as expected in natural displacement ventilation systems (Figure 10d). The stratification means that at a bed height of $1.0 \mathrm{~m}$, temperatures could rise up to $24{ }^{\circ} \mathrm{C}$, which is $3{ }^{\circ} \mathrm{C}$ lower than at similar positions in the ADB ward. The mean temperature at head height is found to be $28{ }^{\circ} \mathrm{C}$, while towards the ceiling, the temperature of collected pockets of stale air collect is up to $31^{\circ} \mathrm{C}$. The relative air change rates predicted from the CFD simulations are in the Nightingale Cruciform ward are 2.1 ACH for default windows Case and 5.5 ACH for NPV Case.

When the Nightingale Cruciform ward is fitted with NPV ducts, the most obvious implication is relative low Age of air $(\approx 180 \mathrm{~s})$ at the air discharge zone of each patient's bed (Figure 11a,b). In addition, there is a lack of significant stratification in temperature throughout the ward (Figure 11c,d). This time, the mean temperature gradient between floor and head level is $2{ }^{\circ} \mathrm{C}$, suggesting a reduction of $4{ }^{\circ} \mathrm{C}$ from the mean temperature obtained in the window case.
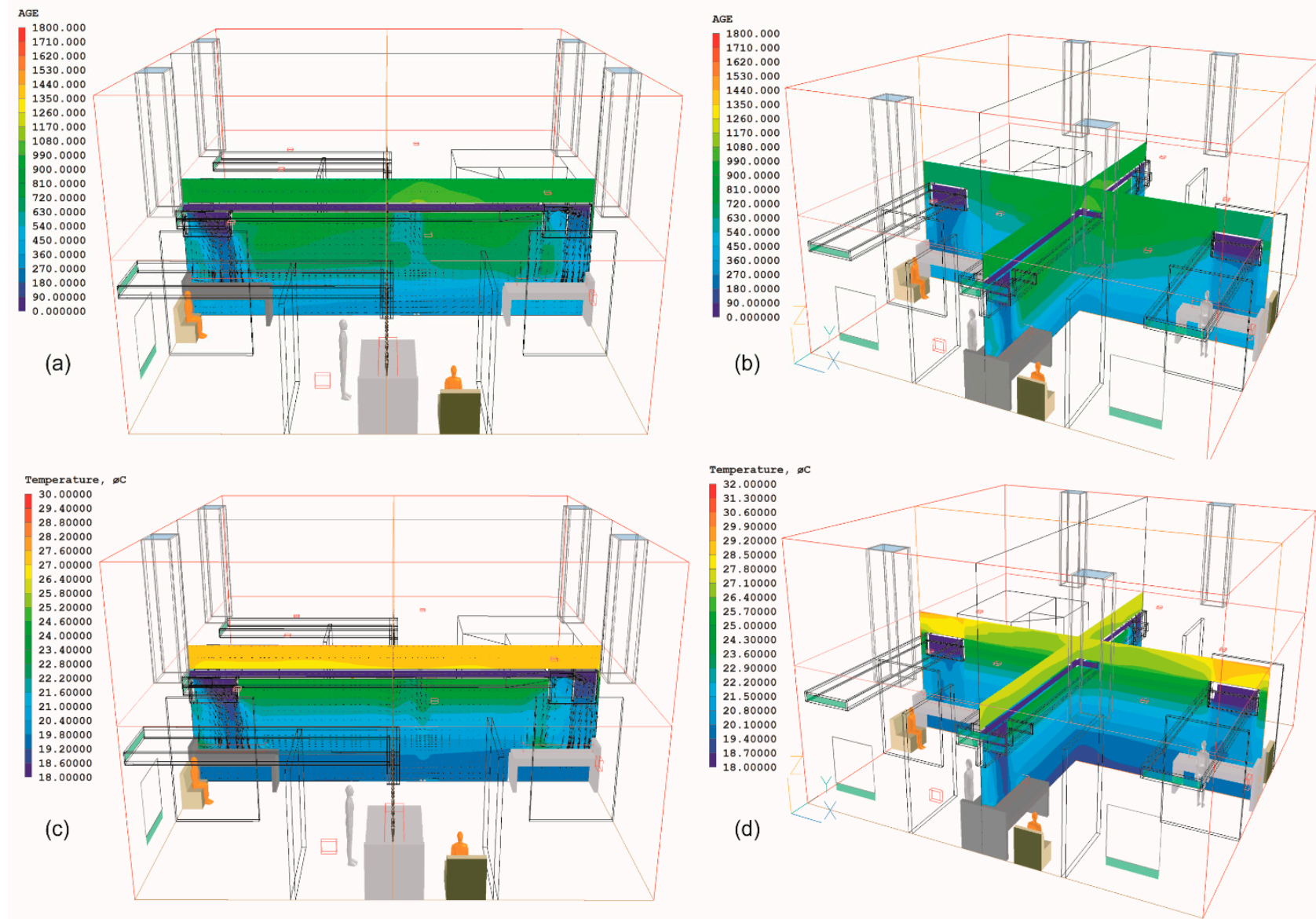

Figure 11. The Cruciform Ward: contours and vectors for age of air shown as: (a) Side view; (b) Isometric view; and for temperature (c) Side view; and (d) Isometric view. 
The NPV ducts (A, B and D) have mean velocities of $\approx 0.32 \mathrm{~m} / \mathrm{s}$, indicating a flow rate of $0.069 \mathrm{~m}^{3} / \mathrm{s}$ or $69 \mathrm{~L} \cdot \mathrm{s}^{-1}$, relative to their cross-sectional areas $($ i.e., $0.18 \mathrm{~m} \times 1.2 \mathrm{~m}$ ). The NPV duct C which is longest, spanning up to $10 \mathrm{~m}$ has a mean velocity of $0.27 \mathrm{~m} / \mathrm{s}$, delivering a mean absolute flow rate of $0.054 \mathrm{~m}^{3} / \mathrm{s}$ or $54 \mathrm{~L} \cdot \mathrm{s}^{-1}$.

The source of scalar airborne contaminant in the Nightingale Cruciform Ward is assumed to be a visitor sitting by the side of Bed A. As the emitted pathogens are discharged towards the ward centre, the lateral spread is restricted to one side due to the presence of partitions (Figure 12a). The central area of the ward receives a relatively significant discharge where the contaminants collect in a pocket. With the NPV system in place, the contaminants discharged are not able to collect in the ward centre. Relative to the window case, dilution at the source location and centre of ward is evident (Figure 12b).

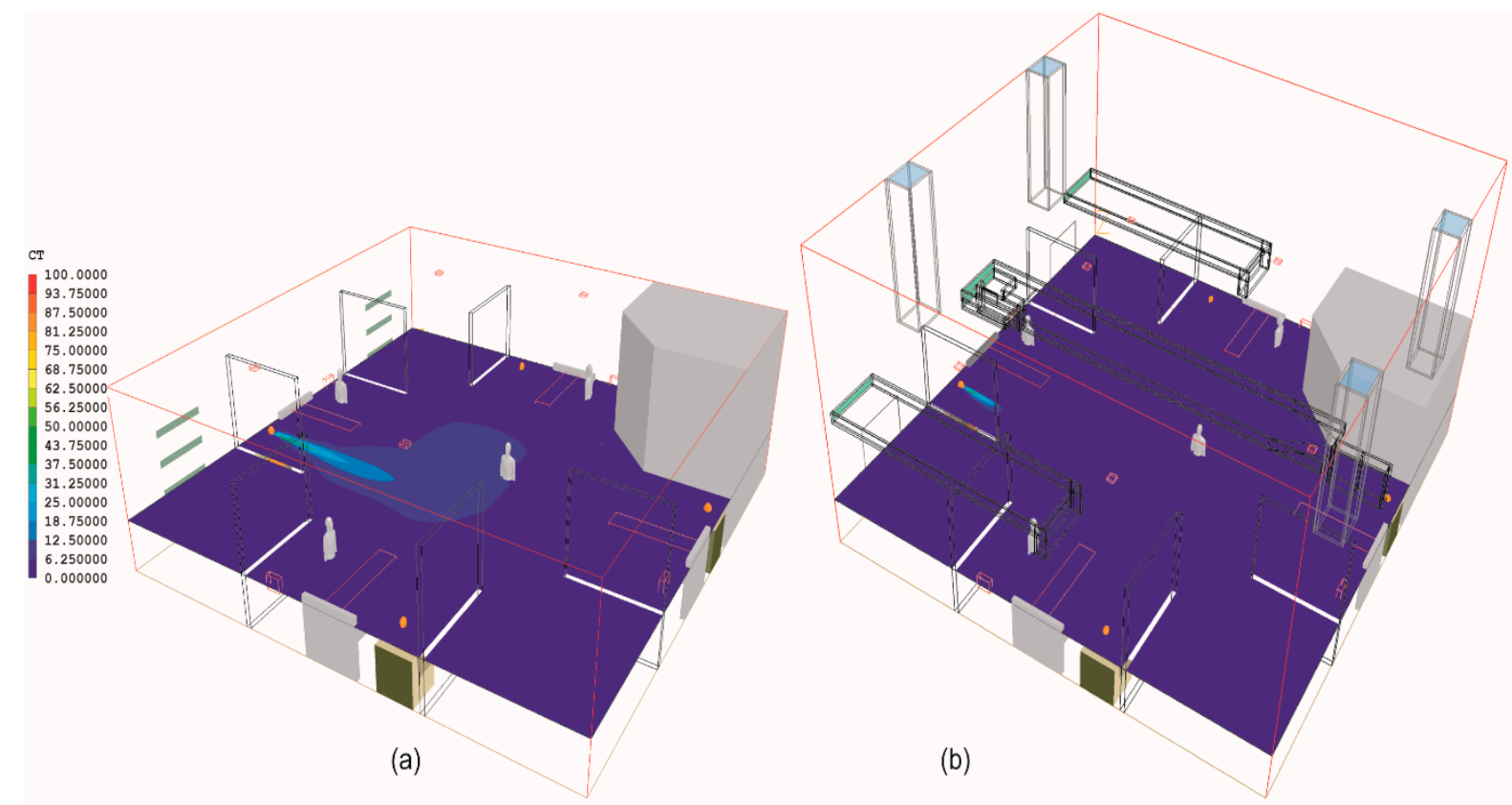

Figure 12. Differences in distribution of passive scalar airborne contaminants in Cruciform Ward based on: (a) Window design; (b) NPV system design.

Both ventilation systems were compared in terms of the differences in efficiency of contaminant removal. It is predicted that the Nightingale Cruciform ward fitted with NPV system would have better CRE in all five key locations (Table 2). Specifically, under the NPV regime, Bed A would have a 71.6\% reduction in CRE compared to Bed $\mathrm{C}$ which has up to $93 \%$ reduction. For the window case, both beds represent the source location and the most ventilated locations, respectively.

Table 2. The CRE values computed at five locations for all three Cases in Cruciform ward.

\begin{tabular}{cccccc}
\hline Cases & Bed A & Bed B & Bed C & Bed D & Ward Centre \\
\hline Cruciform Windows (Case A) & 0.81 & 0.35 & 0.43 & 0.37 & 0.65 \\
Cruciform NPV (Case B) & 0.23 & 0.06 & 0.03 & 0.05 & 0.10 \\
Difference between Window and NPV Cases & $71.6 \%$ & $82.9 \%$ & $93 \%$ & $86.5 \%$ & $84.6 \%$ \\
\hline
\end{tabular}




\section{Assessment of Thermal Comfort Levels in All Wards}

Thermal comfort evaluation of these wards was done using temperature, air velocity, predicted mean vote (PMV) and percentage of people dissatisfied due to draught (PPDR) as the metrics. These parameters were calculated (i.e., measured virtually in CFD model space) directly beneath the point of fresh air discharge, at a height of $1 \mathrm{~m}$ for each bed, using the Probe Object in PHOENICS. In addition, other determinants of thermal comfort, which are similar for all wards include: initial $\mathrm{RH}$ of $50 \%$ for each ward space; Clothing level (Clo)-assumed to be 0.6 for all occupants; and Metabolic rate (Met) assumed to be "Seated and relaxed" for patients. The results for temperature, air velocity, PMV and PPDR for all the ward designs are summarized in Table 3.

Table 3. Thermal comfort variables, showing values at four bed locations at centre of bed (height $=1.0 \mathrm{~m})$.

\begin{tabular}{|c|c|c|c|c|c|c|c|c|c|c|c|c|c|c|c|c|}
\hline \multirow{2}{*}{ Cases } & \multicolumn{4}{|c|}{ Temperature } & \multicolumn{4}{|c|}{ Air Velocity (m/s) } & \multicolumn{4}{|c|}{ PMV * } & \multicolumn{4}{|c|}{ PPDR (\%) } \\
\hline & Bed A & Bed B & Bed C & Bed D & Bed A & Bed B & Bed C & Bed D & Bed A & Bed B & Bed C & Bed D & Bed A & Bed B & Bed C & Bed D \\
\hline ADB: Windows & 27.4 & 27.8 & 27.2 & 27.1 & 0.02 & 0.01 & 0.01 & 0.02 & 1.22 & 1.41 & 1.44 & 1.27 & 0.0 & 0.0 & 0.0 & 0.0 \\
\hline $\begin{array}{c}\text { ADB: } \\
\text { Side-Side NPV }\end{array}$ & 20.3 & 22.1 & 22.3 & 20.1 & 0.13 & 0.07 & 0.08 & 0.12 & -1.72 & -1.06 & -1.1 & -1.81 & 24.0 & 15.4 & 15.8 & 24.2 \\
\hline $\begin{array}{c}\text { ADB: } \\
\text { Top-Bottom } \\
\text { NPV }\end{array}$ & 21.9 & 20.3 & 20.3 & 21.8 & 0.18 & 0.21 & 0.23 & 0.18 & -1.03 & -1.34 & -1.23 & -1.05 & 11.3 & 15.8 & 15.9 & 11.8 \\
\hline $\begin{array}{l}\text { ADB: Modified } \\
\text { Top-Bottom }\end{array}$ & 19.4 & 19.5 & 19.4 & 19.4 & 0.3 & 0.32 & 0.31 & 0.3 & -1.32 & -1.35 & -1.31 & -1.33 & 24.8 & 24.8 & 24.8 & 24.9 \\
\hline $\begin{array}{l}\text { Cruciform: } \\
\text { Windows }\end{array}$ & 24.4 & 24.7 & 25.4 & 24.6 & 0.02 & 0.01 & 0.01 & 0.02 & 0.62 & 0.67 & 0.71 & 0.65 & 0.0 & 0.0 & 0.0 & 0.0 \\
\hline $\begin{array}{c}\text { Cruciform: } \\
\text { NPV }\end{array}$ & 18.5 & 19.2 & 19.4 & 19.1 & 0.1 & 0.09 & 0.06 & 0.09 & -2.25 & -1.68 & -1.63 & -1.71 & 35.9 & 22.5 & 21.2 & 22.3 \\
\hline
\end{tabular}

Notes: * PMV scale: +3 (hot); +2 (warm); +1 (slightly warm); 0 (neutral); -1 (slightly cool); -2 (cool) and -3 (cold).

Based on these thermal comfort results, it can be generalized that the window ventilated (ADB and Cruciform) wards do not have problems with PPDR. In fact, air velocity is hardly noticeable at the points of probe measurement. However, the PMV values of window ventilated wards are relatively poorer than the PMV of NPV ventilated wards (Table 3). The main noticeable thermal comfort concern for the NPV ventilated wards is their PPDR values over the bed.

For the Side-Side NPV design in ADB ward, the predicted PPDR values are between 15\% and 24\% (Table 3). The lower PPDR values belong to the longer ducts which have elbows, leading to lower air velocity for Beds B and C. Due to pressure loss at these bends, these beds (which are furthest from external wall) are expected to experience lesser draught (Figure 5c) than Beds A and D. The less draughty beds (B and C) are therefore warmer (i.e., based on PMV values), than Beds A and D.

With the Top-Bottom NPV design in the ADB ward, the horizontal throw of air (occurring in on Beds A and D) means such patients would not receive much cooler air directly (Figure 5a). This is because a lot of the fresh air is discharged outside the bed (see Figure 8a) leading to slightly higher 
temperatures at the points of measurement. The furthest beds (B and $\mathrm{C}$ ) get direct air discharge (and more draught) due to channel effect. Such draught-related direct discharge of air on Beds B and C is evident in their PMV and PPDR values (Table 1). Similar observations about relatively higher PPDR due to NPV air discharge can be made for the Cruciform ward.

\section{Discussion}

It should be noted that if occupancy and miscellaneous internal heat loads are lower than assumed for this study, then it is likely that the windows would perform better in achieving thermal comfort. Their airborne contaminant dilution capacity could increase as well, but modelling a worse case internal heat load and occupancy scenario is a better risk management strategy. For instance, the overheating potential predicted by this study, the mean ward temperature at head height is $29^{\circ} \mathrm{C}$ and $28{ }^{\circ} \mathrm{C}$ for the ADB and Nightingale Cruciform wards respectively are within the range found [8] concerning overheating in Glenfield Hospital, UK. In future warmer climates, it is likely that such predicted overheating potential as well as low relative ventilation rates could pose serious risks to susceptible occupants due to constricted (maximum of $100 \mathrm{~mm}$ width) window-based natural ventilation. With the NPV system however, the temperature is not stratified and the mixing regime ensures that at head height, the temperature is much lower: $21^{\circ} \mathrm{C}$ for Side-Side NPV and $20^{\circ} \mathrm{C}$ for Top-Bottom NPV (Figure 5a,b). The thermal comfort levels are obviously a function of both outdoor temperature $\left(18^{\circ} \mathrm{C}\right)$ and the internal heat loads and a change in either could lead to different results. However, the main benefit of the NPV system is the delivery of fresh air into relatively deep plans as demonstrated by the two wards studied. The capacity of NPV to induce mixing regime due to the descent of fresh air and its consequent rise and escape as stale air through the stacks. This mixing largely eliminates thermal stratification as observed, ensuring that temperature remains relatively uniform in the areas surrounding the point of fresh air discharge. As observed, the mean Age of air at bed height is significantly lower with the NPV system than window cases, implying the level of air freshness to be expected by patients.

Although, the total area of inlets for the NPV openings is $53 \%$ more than total area of window openings in the ADB case. The ventilation rate obtained from the NPV system in ADB ward depends on the design/arrangement used, but the rate of $4.8 \mathrm{ACH}$ (Side-Side) or 5.2 ACH (Top-Bottom) are significantly higher than the air change rates obtained from window designs (1.8 $\mathrm{ACH})$. In the Nightingale Cruciform ward, the total area of window vents is $20 \%$ more than the total area of NPV openings, yet the ventilation rate obtained for NPV is $5.5 \mathrm{ACH}$ compared to $2.1 \mathrm{ACH}$ for windows. This suggests that appropriate "design" of a natural ventilation system (in this case the duct and stack-based NPV system) can lead to superior airflow rates than merely depending on area of opening (in this case traditional top-hung window system). The role of vertical air channels in restricting the horizontal throw of air fresh air can be appreciated with the improved NPV in the ADB ward as well as in the Cruciform ward. However use of such air channels could mean loss of head room and with the ADB ward, the effective headroom above the bed was $2.45 \mathrm{~m}$, but the headroom in other parts of the ward remained unchanged $(3.6 \mathrm{~m})$. In retrospect, the NPV ducts could have been elevated higher towards the ceiling, but this may mean increasing the length of stack, because distance between openings and stack outlets are important for driving airflow. 
For both types of wards, the Top-Bottom arrangement is found to be a better approach to multi-bed application of the NPV system. The longer (upper) ducts which take fresh air to the furthest beds needed a downward channel to enforce the perpendicular descent of air unto the bed. However, a similar air channel for the shorter (lower) ducts might encroach into the clear head room above the bed. The TopBottom design also has better consistency in airflow rates with speeds of $0.3 \mathrm{~m} / \mathrm{s}$ over a distance of $5 \mathrm{~m}$ in the ADB ward and a speed of $0.27 \mathrm{~m} / \mathrm{s}$ over $10 \mathrm{~m}$ in the longest duct of the Nightingale Cruciform ward. Such consistency in airflow rates would be important for system reliability, particularly for predicting long-term performance and for operation and control purposes. The computed absolute airflow rates for these ducts are $32.4 \mathrm{~L} \cdot \mathrm{s}^{-1}$ and $54 \mathrm{~L} \cdot \mathrm{s}^{-1}$ for ADB and Nightingale Cruciform wards respectively. The airflow rate into via NPV system into Nightingale Cruciform ward approaches the 60 $\mathrm{L} / \mathrm{s} /$ person recommended by the WHO [42] for controlling airborne contaminants in naturally ventilated hospitals. This WHO requirement puts the NPV system into proper context since it can guarantee delivery of fresh air to each patient for effective ventilation. It is also found that the use of vertical air channel is beneficial in redirecting the flow of air downwards. This helps to eliminate the tendency for cooler air to be "thrown" horizontally when entering a warm space [10,25], a phenomenon that was also observed in the experimental validation done of NPV [24] for a single bed ward.

Results obtained for all NPV concepts investigated in this study, suggest that draught is a risk to be taken into account due to the direct discharge of air over the beds. It is observed that the NPV ventilated wards have better PMV values, relative to the windows, but their PPDR values are high. The channel effect, though desirable/intended for re-directing fresh air to where it is most needed (i.e., over the bed) appears to increase PPDR (with knock-on effect on PMV), whereas the elbows in the side-side NPV design actually improve PMV and PPDR due to reduced air velocity. Nevertheless, the actual thermal comfort experiences of occupants (especially patients) will be a function of their clothing and physical condition of health. These are parameters that cannot be modelled easily.

The low CRE from windows in both ADB and Nightingale Cruciform wards cases confirm previous research in which airborne contaminants where found to travel far under displacement [14] as well as their tendency to get trapped in pockets [14,17], needing more time to be diluted. The concentration of contaminants simulated in these cases were relatively high after travelling up to $8 \mathrm{~m}$ (ADB ward) and up $5 \mathrm{~m}$ (Nightingale Cruciform ward). The high CRE values predicted for the NPV in both ward types are consistent with the original findings [23] and the expected behaviour of such a personalised ventilation system.

\section{Conclusions}

The objective of this research was to build on previous work which introduced the NPV system by scaling its application to a multi-bed hospital ward. This required the design of a system for two different kinds of four-bed wards found in the UK. Steady-state CFD was beneficial for predicting and comparing detailed space-based variations in both airflow and contaminant distribution between windows (SNV) and two kinds of NPV systems. The Side-Side and Top-Bottom NPV designs were first modelled using the four-bed ADB ward. Practical design considerations for occupant head room as well as superior airflow characteristics led to the Top-Bottom NPV design being improved by flattening the supply ducts. This flattened duct design was then adopted for studying the four-bed Nightingale Cruciform ward, 
where the NPV system was able to deliver dedicated fresh air to a patient located up to $10 \mathrm{~m}$ away from the external wall. The room air distribution of the NPV system in both types of four-bed wards was a mixing regime, offering better, non-stratified internal temperature as well as improved dilution of passive scalar airborne contaminants. The results support the expected protection from cross-infection, which could be provided to each patient at risk from passive scalar airborne contaminants.

It is however not feasible to use the NPV in its current form during winter in cold climates, unless there is pre-heating of fresh air either within the duct or at point of air discharge (i.e., diffusers). The airflow and mixing/dilution performance of the NPV system therefore, seems a feasible proposition that could improve airflow compared to traditional window-based systems which are restricted by current UK legislation to $100 \mathrm{~mm}$ opening. It is also plausible that in other countries where some form of natural ventilation is practicable all year round, the NPV system can be a practical alternative to traditional window-based ventilation of hospital wards.

\subsection{Limitations of Study}

Exhaled contaminants are often comprised of several droplet sizes of which only a fraction are droplet nuclei that remain airborne. So in its present form, the NPV may not protect against contaminated large droplets or large particulates. This study does not consider the impacts of deposition of contaminated droplets on surfaces and human body. Although posture of coughing patients could also affect exposure to coughed airborne pathogens [44] only the uni-directional emission from a seated visitor was considered. We also acknowledge that modelling the NPV system under a wider temperature range would be beneficial, but this has not been done, given the conceptual scope of this work. Finally, in reality, PV systems would have control mechanisms allowing each user to regulate the flow of air including its speed, direction and possibly temperature, but for the scope of this paper and the exploratory nature of this CFD-based investigation, such control mechanisms were not modelled. Due to limitation of the PHOENICS simulation application, RH could not be measured at specific points inside the ward. Hence, it is unclear at this stage, the extent to which humidity varies as a result of direct discharge of fresh air over the beds through the NPV system. Many of these limitations will be tackled in subsequent work.

\subsection{Further Work}

Full-scaled experiments are planned for the NPV system in either a real hospital ward or in a mock-up ward. In such experiments, a wider range of outdoor temperature would be used to test whole year performance of the system, but obviously, pre-heating of fresh air would be needed in winter. The airflow performance of NPV ducts should also improve using circular ducts but in the studies carried out so far, software constraints have limited the duct design to rectangular shapes. For future full-scale experiments, the desirability of flattened ducts in Top-Bottom arrangement might rule out circular ducts, however, a series of small radius ducts could be arranged in parallel. This circular duct concept could offer further opportunity for users to control airflow delivery by switching some ducts on or off. 


\section{Author Contributions}

The first author was responsible for carrying out simulations and putting together the results/analysis, while the second author provided guidance/direction on the research, as well as proof reading and editing of the paper.

\section{Conflicts of Interest}

The authors declare no conflict of interest.

\section{References and Notes}

1. Department of Health (NHS Estates). Health Technical Memorandum 07-02: EnCO2de-, Making Energy Work in Healthcare, Environment and Sustainability; Department of Health Estates and Facilities Division, The Stationary Office: London, UK, 2006.

2. Short, C.A.; Cook, M.; Cropper, P.C.; Al-Maiyah, S. Low-energy refurbishment strategies for health buildings. J. Build. Perform. Simul. 2010, 3, 197-216.

3. Qian, H.; Li, Y.; Seto, W.H.; Ching, P.; Ching, W.H.; Sun, H.Q. Natural ventilation for reducing airborne infection in hospitals. Build. Environ. 2010, 45, 559-565.

4. Escombe, A.R.; Oeser, C.C.; Gilman, R.H.; Navincopa, M.; Ticona, E.; Pan, W.; Martínez, C.; Chacaltana, J.; Rodríguez, R.; Moore, D.A.J.; et al. Natural ventilation for the prevention of airborne contagion. PLoS Med. 2007, 4, 309-317.

5. Department of Health (NHS Estates). Health Technical Memorandum HTM 55 (Building Components) Windows; The Stationery Office: London, UK, 1998.

6. Department of Health (NHS Estates). Health Building Note 00-10 Part D: Windows and Associated Hardware; Department of Health: London, UK, 2013. Available online: http://www.dhsspsni.gov.uk/hbn00-01-partd.pdf (accessed on 12 January 2014).

7. Gilkeson, C.A.; Camargo-Valero, M.A.; Pickin, L.E.; Noakes, C.J. Measurement of ventilation and airborne infection risk in large naturally ventilated hospital wards. Build. Environ. 2013, 65, 35-48.

8. Giridharan, R.; Lomas, K.J.; Short, C.A.; Fair, A.J. Performance of hospital spaces in summer: A case study of a "Nucleus"-type hospital in the UK Midlands. Energy Build. 2013, 66, 315-328.

9. Lomas, K.J. Architectural design of an advanced naturally ventilated building form. Energy Build. 2007, 39, 166-181.

10. Awbi, H.B. Ventilation of Buildings, 2nd ed.; Spon Press: London, UK, 2003.

11. Moodie, T.B. Gravity currents. J. Comput. Appl. Math. 2002, 144, 49-83.

12. Chen, C.; Zhu, J.; Qu, Z.; Lin, C.-H.; Jiang, Z.; Chen, Q. Systematic study of person-to-person contaminant transport in mechanically ventilated spaces. HVAC\&R Res. 2014, 20, 80-91.

13. Gao, N.; He, Q.; Niu, J. Numerical study of the lock-up phenomenon of human exhaled droplets under a displacement ventilated room. Build. Simul. 2012, 5, 51-60.

14. Li, Y.; Nielsen, P.V.; Sandberg, M. Displacement ventilation in hospital environments. ASHRAE J. 2011, 53, 86-88.

15. Beggs, C.B.; Kerr, K.G.; Noakes, C.J.; Hathway, E.A.; Sleigh, P.A. The ventilation of multiple-bed hospital wards: Review and analysis. Am. J. Infect. Control 2008, 36, 250-259. 
16. Qian, H.; Li, Y.; Nielsen, P.V.; Hyldgaard, C.E.; Wong, T.W.; Chwang, A.T.Y. Dispersion of exhaled droplet nuclei in a two-bed hospital ward with three different ventilation systems. Indoor Air 2006, 16, 111-128.

17. Olmedo, I.; Nielsen, P.V.; Ruiz de Adana, M.; Jensen, R.L.; Grzelecki, P. Distribution of exhaled contaminants and personal exposure in a room using three different air distribution strategies. Indoor Air 2012, 22, 64-76.

18. Melikov, A. Personalized ventilation. Indoor Air 2004, 14, 157-167.

19. Yang, B.; Sekhar, C.; Melikov, A.K. Ceiling mounted personalized ventilation system in hot and humid climate-An energy analysis. Energy Build. 2010, 42, 2304-2308.

20. Melikov, A.; Ivanova, T.; Stefanova, G. Seat headrest-incorporated personalized ventilation: Thermal comfort and inhaled air quality. Build. Environ. 2012, 47, 100-108.

21. Cermak, R.; Melikov, A. Protection of occupants from exhaled infectious agents and floor material emissions in rooms with personalized and underfloor ventilation. HVAC\&R Res. 2007, 13, 23-38.

22. Cermak, R.; Melikov, A.K.; Forejt, L.; Kovar, O. Performance of personalized ventilation in conjunction with mixing and displacement ventilation. $H V A C \& R$ Res. 2006, 12, 295-311.

23. Adamu, Z.A.; Cook, M.J.; Price, A.D.F. Natural personalised ventilation: A novel approach. Int. J. Ventil. 2011, 10, 263-275.

24. Todd, S.P.; Adamu, Z.A.; Cook, M.J.; Price, A.D.F. Natural Personalised Ventilation for Hospital Wards: Experimental Validation. In Proceedings of the 4th CIBSE ASHRAE Technical Symposium, Dublin, Ireland, 3-4 April 2014.

25. Koestel, A. Paths of horizontally projected heated and chilled air jets. Trans. ASHAF 1955, 61, 231-232.

26. Li, Y.; Nielsen, P.V. CFD and ventilation research. Indoor Air 2011, 21, 442-453.

27. Chen, Q. Ventilation performance prediction for buildings: A method overview and recent applications. Build. Environ. 2009, 44, 848-858.

28. Chen, Q. Using computational tools to factor wind into architectural environment design. Energy Build. 2004, 36, 1197-1209.

29. CHAM. Phoenics version 2009. Cham Co. Ltd.: Wimbledon, UK, 2014. Available online: http://www.cham.co.uk/ (accessed on 5 July 2013).

30. Yakhot, V.; Orszag, S.A. Renormalization group analysis of turbulence. J. Sci. Comput. 1986, 1, 3-51.

31. Mundt, M.; Mathisen, H.M.; Moser, M.; Nielsen, P.V. REHVA Ventilation Effectiveness Guide; Federation of European Heating, Ventilation and Air-Conditioning Association: Brussels, Belgium, 2004. Available online: http://www.rehva.eu/publications-and-resources/guidebooks-shop/ (accessed on 8 August 2012).

32. Cheong, K.W.D.; Phua, S.Y. Development of ventilation design strategy for effective removal of pollutant in the isolation room of a hospital. Build. Environ. 2006, 41, 1161-1170.

33. Olesen, B.W. The philosophy behind EN 15251: Indoor environmental criteria for design and calculation of energy performance of buildings. Energy Build. 2007, 39, 740-749.

34. The Chartered Institution of Building Services Engineers (CIBSE). Guide A: Environmental Design; CIBSE: London, UK, 2006. 
35. Jiang, Y.; Zhao, B.; Li, X.; Yang, X.; Zhang, Z.; Zhang, Y. Investigating a safe ventilation rate for the prevention of indoor SARS transmission: An attempt based on simulation approach. Build. Simul. 2009, 2, 281-289.

36. Morawska, L. Droplet fate in indoor environments, or can we prevent the spread of infection? Indoor Air 2006, 16, 335-347.

37. Cox, C.S.; Wathes, C.M. Bioaerosols Handbook; Lewis Publishers: Boca Raton, FL, USA, 1995; p. 17.

38. Gupta, J.; Lin, C.-H.; Chen, Q. Flow dynamics and characterization of a cough. Indoor Air 2009, 19, 517-525.

39. Des Prez, R.M.; Heim, C.R. Mycobacterium Tuberculosis. In Principles and Practices of Infectious Diseases; Mandell, G.L., Douglas, R.G., Jr., Bennett, J.E., Eds.; Churchill Livingston: New York, NY, USA, 1990; pp. 1877-1906.

40. Lomas, K.J.; Ji, Y. Resilience of naturally ventilated buildings to climate change: Advanced natural ventilation and hospital wards. Energy Build. 2009, 41, 629-653.

41. Paradise, C. Innovative Patient Accommodation. In Proceedings of International Academy for Design and Health 7th World Congress and Exhibition, Boston, MA, USA, 6-10 July 2011. Available online: http://www.designandhealth.com/uploaded/documents/Awards-and-events/ WCDH2011/Presentations/Friday/Session-8/CarolineParadise.pdf (accessed on 5 January 2013).

42. Natural Ventilation for Infection Control in Health-Care Settings; Atkinson, J., Chartier, Y., PessoaSilva, C.L., Jensen, P., Li, Y., Seto, W.-H., Eds.; WHO: Geneva, Switzerland. 2009. Available online: http://www.who.int/water_sanitation_health/publications/natural_ventilation.pdf (accessed on 18 May 2012).

43. Li, Y.; Leung, M.K.H.; Seto, W.H.; Yeun, P.L.; Leung, J.; Kwan, J.K.; Yu, S.C.T. Factors affecting ventilation effectiveness in SARS wards. Hong Kong Med. J. 2008, 14, 33-36.

44. Kierat, W.; Bolashikov, Z.D.; Melikov, A.K.; Popiołek, Z.; Brand, M. Exposure to Coughed Airborne Pathogens in a Double Bed Hospital Patient Room: Impact of Posture of Coughing Patient and Location of Doctor. In Proceedings of the ASHRAE IAQ Conference, Kuala Lumpur, Malaysia, 10-12 November 2010; paper 128.

(C) 2015 by the authors; licensee MDPI, Basel, Switzerland. This article is an open access article distributed under the terms and conditions of the Creative Commons Attribution license (http://creativecommons.org/licenses/by/4.0/). 